\title{
Bartonella infections in cats and dogs including zoonotic aspects
}

\author{
Alejandra Álvarez-Fernández', Edward B. Breitschwerdt ${ }^{2}$ and Laia Solano-Gallego ${ }^{1 *}$ (D)
}

\begin{abstract}
Bartonellosis is a vector-borne zoonotic disease with worldwide distribution that can infect humans and a large number of mammals including small companion animals (cats and dogs). In recent years, an increasing number of studies from around the world have reported Bartonella infections, although publications have predominantly focused on the North American perspective. Currently, clinico-pathological data from Europe are more limited, suggesting that bartonellosis may be an infrequent or underdiagnosed infectious disease in cats and dogs. Research is needed to confirm or exclude Bartonella infection as a cause of a spectrum of feline and canine diseases. Bartonella spp. can cause acute or chronic infections in cats, dogs and humans. On a comparative medical basis, different clinical manifestations, such as periods of intermittent fever, granulomatous inflammation involving the heart, liver, lymph nodes and other tissues, endocarditis, bacillary angiomatosis, peliosis hepatis, uveitis and vasoproliferative tumors have been reported in cats, dogs and humans. The purpose of this review is to provide an update and European perspective on Bartonella infections in cats and dogs, including clinical, diagnostic, epidemiological, pathological, treatment and zoonotic aspects.
\end{abstract}

Keywords: Bartonella, Dog, Cat, Europe, Zoonosis

\section{Background}

Bartonella is a genus of Alphaproteobacteria within the family Bartonellaceae. Bartonella spp. are small, thin, short and slightly curved, gram-negative, hemotropic and rod-shaped bacteria [1]. They are catalase, oxidase, urease and nitrate reductase negative [1]. Bartonella spp. are fastidious, slow growing and facultative intracellular pathogens that are highly adapted to a broad spectrum of mammalian reservoir hosts and are mainly transmitted by arthropod vectors [2, 3]. Thirty-eight different Bartonella species have been isolated or detected from humans or from domestic and wild animals including bats, birds, canids, cattle, deer, felids, horses, marine mammals, rodents, sheep and reptiles [4-10]. Bartonella spp. are distributed throughout the world. In recent years, an increasing number of studies from around the world have reported canine and feline Bartonella infections. The purpose of this review is to provide an update while emphasizing European literature relative to Bartonella spp. infections in cats and dogs, including clinical,

\footnotetext{
* Correspondence: laia.solano@uab.cat

${ }^{1}$ Departament de Medicina i Cirurgia Animals, Facultat de Veterinària,

Universitat Autònoma de Barcelona, 08193 Bellaterra, Spain

Full list of author information is available at the end of the article
}

diagnostic, epidemiological, pathological, treatment and zoonotic aspects.

\section{Clinically relevant Bartonella species described in cats, dogs and humans}

At least thirteen Bartonella species or subspecies have been recognized as agents of human disease, three species are reportedly responsible for the majority of clinical illness: B. bacilliformis, B. quintana and B. henselae [11]. Because serological testing for other Bartonella spp. is rarely performed in human medicine and due to difficulties associated with isolation or PCR amplification of these bacteria from patient specimens, it is possible that B. koehlerae [12, 13], B. vinsonii berkhoffii, as well as other species are under-recognized as a cause of human illness $[14,15]$.

Primary reservoirs, accidental hosts and the confirmed or suspected vectors for the main Bartonella species infecting cats and dogs with zoonotic potential are listed in Table 1. The most relevant species implicated in companion animal medicine are B. clarridgeiae, B. elizabethae, $B$. henselae, B. koehlerae, B. quintana, $B$. rochalimae and $B$. vinsonii berkhoffii. All of these species have been associated with severe illnesses in cats or dogs 
Table 1 Bartonella species that infect cats and dogs with zoonotic potential including primary reservoir, accidental host and vectors

\begin{tabular}{|c|c|c|c|}
\hline Bartonella species & Primary reservoir & Vector & Accidental host \\
\hline B. bovis (ex weissii) & Domestic cattle (Bos taurus) & Biting flies, ticks & Humans, cats, dogs \\
\hline B. volans-like & Flying squirrel (Pteromyinae) & Fleas & Humans, dogs, horses \\
\hline B. clarridgeiae & Cats (Felis catus) & Cat flea (Ctenocephalides felis), ticks ${ }^{a}$ & Humans, dogs \\
\hline B. elizabethae & Rats (Rattus norvegicus) & Fleas & Humans, dogs \\
\hline B. grahamii & Rodents & Rodent flea (Ctenophthalmus nobilis) & Humans, dogs \\
\hline B. henselae & Cats (Felis catus), dogs (Canis familiaris) & Fleas, ticks ${ }^{a}$ & Human, dogs \\
\hline B. koehlerae & Cats (Felis catus), gerbils (Meriones lybicus) & Fleas & Humans, dogs \\
\hline B. quintana & Humans, gerbils (Meriones lybicus) & $\begin{array}{l}\text { Human body lice, fleas, bed bugs, } \\
\text { pigeon mites }{ }^{\mathrm{a}}\end{array}$ & Cats, dogs, monkeys \\
\hline B. rochalimae & Canids & Fleas $^{\mathrm{a}}$ (Pulex irritans, Pulex simulans), ticks ${ }^{\mathrm{a}}$ & Humans, dogs \\
\hline B. vinsonii arupensis & Rodents & Deer tick (Ixodes scapularis) & Humans, dogs \\
\hline B. vinsonii berkhoffii & $\begin{array}{l}\text { Coyotes (Canis latrans), dogs (Canis familiaris), } \\
\text { foxes (Urocyon spp.) }\end{array}$ & Ticks $^{a}$, Pulex spp. ${ }^{a}$ & Humans \\
\hline B. washoensis & $\begin{array}{l}\text { California ground squirrel (Spermophilus beecheyi), } \\
\text { rabbits (Oryctolagus cuniculus) }\end{array}$ & Fleas, ticks ${ }^{a}$ & Humans, dogs \\
\hline
\end{tabular}

${ }^{\mathrm{a}}$ Not confirmed

Details included in the table are provided in [16, 25, 40, 53, 57, 132, 175-183]

and all have zoonotic potential [16, 17]. Each Bartonella spp. appears to have co-evolved with a specific primary reservoir host which poses a source of infection for accidental hosts under natural exposure conditions [16].

The cat (Felis catus) is the primary but not sole reservoir for B. henselae [18], the causal agent of human cat scratch disease (CSD). Domestic cats are also principal reservoir hosts for B. clarridgeiae and B. koehlerae. Infected cats are thought to rarely develop clinical signs [19]. However, chronic, relapsing bacteremia can frequently be detected in infected cats and potential long-term consequences of relapsing bacteremia are unknown [20-22]. Cats can also be infected with B. bovis (ex weissii) and B. quintana, but the role of domestic cats in the epidemiology of these two Bartonella species has not been clearly established [21].

The dog (Canis familiaris) may also be a host for $B$. henselae and canines are considered the primary reservoirs for B. vinsonii berkhoffii, causing endocarditis in dogs and humans [23, 24]. Wild canids such as coyotes (Canis latrans) in California and potentially domestic dogs have been described as main reservoir hosts for $B$. vinsonii berkhoffii, as prolonged bacteremia also occurs in these animals $[5,25,26]$. Bartonella henselae, first isolated from a dog in Gabon in 2003 may be the Bartonella spp. that most often infects pet dogs [27]. Dogs can also be infected with B. clarridgeiae, B. elizabethae, B. koehlerae, B. quintana, B. rochalimae and B. washoensis, potentially causing similar disease manifestations as reported in humans, including bacillary angiomatosis, endocarditis, granulomatous hepatitis and granulomatous lymphadenitis, myocarditis, peliosis hepatis and others [20, 28-32]. Due to direct and frequent contact with humans, pet and stray infected cats and dogs pose a potential risk for human infection [33].

Bartonella henselae also causes multiple other clinical entities in human patients, potentially related to the individual's immune status, variations in strain virulence, co-infection with other pathogens and co-morbidities [34]. Infection with B. clarridgeiae has been suspected in a few CSD cases and the organism has been isolated from one asymptomatic human blood donor [35]. Bartonella koehlerae has been associated with regional pain syndrome type I [13], hallucinations, sensory neuropathy, peripheral visual deficits [36], endocarditis [22] and other clinical conditions [12]. Bartonella vinsonii berkhoffii has been associated with human endocarditis and a spectrum of neurological symptoms [23, 24]. Bartonella quintana, the agent of trench fever, has been classically considered a human-specific species transmitted solely by human body lice [37]. However, B. quintana DNA has been detected in dogs with endocarditis [38] and healthy dogs $[39,40]$, cats $[41,42]$ and monkeys (Macaca fascicularis and Macaca mulatta) [43, 44].

\section{Inter- and intra-species transmission}

Intra-erythrocytic Bartonella organisms within the bloodstream are ingested by blood-sucking arthropod vectors, mainly fleas, lice, sand flies, biting flies and ticks, after which they are transmitted to a primary reservoir or to an accidental host [37] (Table 1). Vector transmission occurs in two primary ways: (i) inoculation of Bartonella-contaminated arthropod feces via animal scratches or bites or by self-inflected contamination of wounds induced by the host scratching irritating arthropod bites. These are important modes of transmission 
among primary reservoir and accidental hosts, including cats, dogs and humans [45-47]. (ii) The other primary mode of transmission is by vector bites, as confirmed for Lutzomyia verrucarum sand flies, the vector of B. bacilliformis among humans [48]. Experimentally, using an in vitro model, Ixodes ricinus ticks were able to infect mammalian blood with $B$. henselae [49]. Furthermore, the presence of Bartonella spp. DNA, particularly $B$. henselae, has been well documented in questing ticks from Europe and other continents [50-52]. Ticks have also been clinically implicated in the transmission of Bartonella infection to dogs or humans in the absence of other vectors or known modes of transmission [5356]. Interestingly, regurgitation of $B$. henselae by cat fleas (Ctenocephalides felis) has been demonstrated experimentally [57], but additional studies are needed to confirm flea-bite transmission to animals or humans. It is important to note that non-vectorial modes of transmission are also possible such as transmission through needle stick injury to veterinarians [58] or by blood transfusion as documented experimentally in cats, dogs and humans [59-62].

\section{Epidemiology, prevalence and distribution in Europe}

Serology, PCR or culture-based clinico-epidemiological studies in cats and dogs in Europe are summarized in Tables 2 and 3 and Figs. 1 and 2. More than 50 feline and canine seroprevalence studies have been reported from different European countries (Tables 2, 3); however, culture or PCR confirmed cases of canine or feline bartonellosis have been infrequently reported. Bartonella spp. seroprevalence rates are high in cats in European Mediterranean countries, where temperature and humidity are favorable for flea and tick infestations [20] (Fig. 1). In Europe, Bartonella antibody prevalence in cats ranges from $0 \%$ in Norway [63] to $71.4 \%$ in Spain [64] (Table 2). Bacteremic prevalence rates for various combinations of B. clarridgeiae, B. henselae and B. koehlerae often approach $50-75 \%$ in feral cat populations worldwide [17]. Generally, the differences in serological or bacteremic prevalences are related to different climatic conditions, whether the cat population tested consisted of pet or stray cats and whether acaricide products were used routinely. Information regarding clinic-epidemiological studies performed in cats in other continents is summarized in Table 4.

Bartonella henselae infection is commonly encountered in cats and potentially dogs and humans worldwide [65] (Tables 2, 3, 4, 5). Bartonella clarridgeiae, B. quintana, $B$. koehlerae and $B$. bovis are less frequently isolated from domestic cats than $B$. henselae, potentially because these species are more difficult to isolate or are unevenly distributed worldwide (Tables 2, 4). In Europe,
B. clarridgeiae serological and molecular prevalence rates vary from 17 to $36 \%$, while $B$. quintana seroprevalence rates range from 0 to $18 \%$, among a few reported studies (Table 2). Interestingly, B. koehlerae and B. bovis have not yet been documented to infect cats in Europe although $B$. koehlerae DNA has been amplified from cat fleas in France [66].

Bartonella exposure or infection prevalence studies involving cats have been widely reported from around the world (Tables 2, 4), whereas fewer serological or isolation studies are available regarding Bartonella exposure or infection in dogs (Fig. 2). In the USA, one study found a $3.6 \%$ B. vinsonii berkhoffii seroprevalence in 1920 clinically ill dogs. The B. vinsonii berkhoffii seroprevalence increased to 36 and $52 \%$ if the dogs were co-exposed to Ehrlichia canis or Babesia canis, respectively [67]. Another study found B. henselae IgG antibodies in $10.1 \%$ of healthy dogs and in $27.2 \%$ of sick dogs, whereas B. vinsonii berkhoffii IgG antibodies were detected in only $1 \%$ of healthy dogs and $4.7 \%$ of sick dogs [68]. A recent Bartonella seroepidemiology study from North America found overall low B. henselae, $B$. koehlerae and $B$. vinsonii berkhoffii seroprevalences in dogs in which a vector-borne disease was suspected [69]. In California, 102 out of 3417 (2.99\%) sick dogs were seroreactive for at least one species of Bartonella antigen. Of these, 36 (35.3\%) had antibodies against B. henselae only, $34(33.3 \%)$ had antibodies against $B$. clarridgeiae only, $2(2.0 \%)$ had antibodies against $B$. vinsonii berkhoffii only and $30(29.4 \%)$ had antibodies against a combination of these antigens [70]. Although the sensitivity of Bartonella spp. indirect immunofluorescence assay (IFA) most likely under estimates overall seroprevalence, IFA specificity appears to approach $100 \%$ [71]. Bartonella seroprevalence data is more limited in Europe and other continents in dogs when compared to North America (Tables 3, 5). In Europe, 3\% were $B$. henselae-seropositive in the UK [72] and $5.8 \%$ in Italy [73]. In Spain, B. henselae and B. vinsonii berkhoffii seroprevalences were 16.8 and $1.1 \%$, respectively [74]. Moreover, it is important to remark that after a search in PubMed we found around seven times more reports of Bartonella infection in dogs in the USA than in Europe [5, 14, 28-31, 38, 75-100]. Information regarding clinico-epidemiological studies performed in dogs in other continents is summarized in Table 5.

The annual number of human cases of CSD in the USA is estimated to be 12,000 outpatients and 500 inpatients [101]. Comparative data have not been reported for European countries. By IFA testing, B. henselae seroprevalence rates reported for humans in Europe range between 3 and $30 \%[51,102,103]$. A recent study that used six Bartonella spp. or genotype antigens to test 89 Spanish veterinarians documented a high Bartonella spp. seroprevalence 
Table 2 Bartonella spp. clinico-epidemiological studies involving cats in Europe

\begin{tabular}{|c|c|c|c|c|c|c|}
\hline \multirow[t]{2}{*}{ Country (area, year) } & \multirow{2}{*}{$\begin{array}{l}\text { Total no. of animals } \\
\text { studied (lifestyle) }\end{array}$} & \multicolumn{3}{|c|}{ Percentage of positive animals } & \multirow{2}{*}{$\begin{array}{l}\text { Confirmed Bartonella } \\
\text { spp. and type using } \\
\text { molecular methods }\end{array}$} & \multirow[t]{2}{*}{ Reference } \\
\hline & & $\begin{array}{l}\text { Serology (method } \\
\text { or antigen used) }\end{array}$ & $\begin{array}{l}\text { Blood } \\
\text { PCR }\end{array}$ & $\begin{array}{l}\text { Blood } \\
\text { culture }\end{array}$ & & \\
\hline Albania (Tirana, 2014) & 146 (client-owned) & $\mathrm{nr}$ & 0.7 & $\mathrm{nr}$ & B. henselae & [182] \\
\hline Cyprus (2017) & $\begin{array}{l}174 \text { (stray and } \\
\text { client-owned) }\end{array}$ & $\mathrm{nr}$ & 10.9 & $\mathrm{nr}$ & B. henselae & [183] \\
\hline $\begin{array}{l}\text { Greece (Crete, Mykonos, Skopelos, } \\
\text { Athens, 2017) }\end{array}$ & 148 (stray) & 58.8 & 4.7 & $\mathrm{nr}$ & B. henselae, B. clarridgeiae & [184] \\
\hline Greece (Thessaly, Macedonia, 2018) & 100 (client-owned) & $\mathrm{nr}$ & 8.5 & $\mathrm{nr}$ & $\begin{array}{l}\text { B. henselae, B. clarridgeiae, } \\
\text { B. koehlerae }\end{array}$ & [178] \\
\hline Czech Republic (Prague, 2003) & $\begin{array}{l}61 \text { (stray, client-owned } \\
\text { and shelter) }\end{array}$ & $\mathrm{nr}$ & $\mathrm{nr}$ & 8.0 & B. henselae type II & [185] \\
\hline Denmark (2002) & $\begin{array}{l}93 \text { (stray and } \\
\text { client-owned) }\end{array}$ & 45.6 & $\mathrm{nr}$ & 22.6 & B. henselae types I and II & [186] \\
\hline France (Nancy, 1997) & 94 (stray) & $\mathrm{nr}$ & $\mathrm{nr}$ & 53 & $\begin{array}{l}\text { B. henselae types I and II, } \\
\text { B. clarridgeiae }\end{array}$ & [187] \\
\hline France (Paris, 2001) & 436 (client-owned) & 41.1 & $\mathrm{nr}$ & 16.5 & $\begin{array}{l}\text { B. henselae types I and II, B. } \\
\text { clarridgeiae }\end{array}$ & [188] \\
\hline France (Lyon, 2004) & 99 (client-owned) & $\mathrm{nr}$ & $\mathrm{nr}$ & 8.1 & B. henselae, B. clarridgeiae & [189] \\
\hline Germany (Freiburg, 1997) & 100 (client-owned) & $\mathrm{nr}$ & $\mathrm{nr}$ & 13 & B. henselae & [190] \\
\hline $\begin{array}{l}\text { Germany (southern and northern, } \\
\text { 1999) }\end{array}$ & $\begin{array}{l}713 \text { (stray and } \\
\text { client-owned) }\end{array}$ & 1 & $\mathrm{nr}$ & $\mathrm{nr}$ & $\mathrm{nr}$ & [191] \\
\hline Germany (Berlin, 2001) & $\begin{array}{l}193 \text { (client-owned } \\
\text { and stray) }\end{array}$ & $\mathrm{nr}$ & $\mathrm{nr}$ & 20 & $\begin{array}{l}\text { B. henselae types I and II, B. } \\
\text { clarridgeiae }\end{array}$ & [192] \\
\hline $\begin{array}{l}\text { Germany (Hannover and others, } \\
\text { 2011) }\end{array}$ & $507(\mathrm{nr})$ & 68.7 (ELISA) & $\mathrm{nr}$ & 2.2 & B. henselae & [193] \\
\hline Germany (north-east, 2012) & $\begin{array}{l}256 \text { (stray and } \\
\text { client-owned) }\end{array}$ & 37.1; 18.8 (B. quintana) & 0 & $\mathrm{nr}$ & na & [194] \\
\hline Germany (southern, 2017) & $479(\mathrm{nr})$ & $\mathrm{nr}$ & 2.5 & $\mathrm{nr}$ & B. henselae, B. clarridgeiae & [195] \\
\hline Italy (Tuscany, 2002) & $\begin{array}{l}427 \text { (client-owned } \\
\text { and shelter) }\end{array}$ & 16.0 & 4.0 & 0 & B. henselae & [196] \\
\hline Italy (northern, 2002) & $248(\mathrm{nr})$ & $\mathrm{nr}$ & $\mathrm{nr}$ & 9.7 & B. henselae & [197] \\
\hline Italy (northern, 2004) & 1585 (stray) & 39.0 & $\mathrm{nr}$ & 2.0 & $\begin{array}{l}\text { B. henselae types I and II, } \\
\text { B. clarridgeiae }\end{array}$ & [198] \\
\hline Italy (Sassari, 2007) & $\begin{array}{l}79 \text { (stray and } \\
\text { client-owned) }\end{array}$ & 21.5 & $\mathrm{nr}$ & $\mathrm{nr}$ & na & [199] \\
\hline Italy (Sardinia, 2009) & $55(\mathrm{nr})$ & 10.9 & 5.5 & $\mathrm{nr}$ & B. henselae & [73] \\
\hline Italy (southern, 2010) & 85 (client-owned) & $\mathrm{nr}$ & 83.5 & $\mathrm{nr}$ & B. henselae & [148] \\
\hline Italy (Sicily, 2012) & $\begin{array}{l}182 \text { (stray and } \\
\text { client-owned) }\end{array}$ & 57.1 & $\mathrm{nr}$ & $\mathrm{nr}$ & na & {$[200]$} \\
\hline Italy (Pisa, 2012) & 234 (client-owned) & 33.3 & 11.1 & $\mathrm{nr}$ & B. henselae types I and II & [201] \\
\hline Italy (northern, 2013) & 1340 (stray) & 23.1 & $\mathrm{nr}$ & 17.0 & B. henselae, B. clarridgeiae & [202] \\
\hline Italy (northern, 2016) & 82 (stray) & 30.4 & $\mathrm{nr}$ & $\mathrm{nr}$ & na & [203] \\
\hline Italy (southern, 2016) & $42(n r)$ & 54.8 & 38.1 & $\mathrm{nr}$ & B. henselae, B. clarridgeiae & [204] \\
\hline Italy (Aeolian Islands, 2017) & 330 (client-owned) & $\mathrm{nr}$ & 3.9 & $\mathrm{nr}$ & B. henselae, B. clarridgeiae & [205] \\
\hline Ireland (Dublin area, 2010) & 121 (client-owned) & 26.5 (ELISA) & 5.2 & $\mathrm{nr}$ & $\begin{array}{l}\text { B. henselae type II, } \\
\text { B. clarridgeiae }\end{array}$ & {$[206]$} \\
\hline Netherlands (1997) & $\begin{array}{l}163 \text { (stray and } \\
\text { client-owned) }\end{array}$ & 51.8 (ELISA) & $\mathrm{nr}$ & 22.0 & B. henselae & [207] \\
\hline Norway (2002) & $\begin{array}{l}100 \text { (stray and } \\
\text { client-owned) }\end{array}$ & 0 & $\mathrm{nr}$ & 0 & na & {$[63]$} \\
\hline Poland (Varsaw, 2007) & $137(\mathrm{nr})$ & 45.0 & 10.2 & $\mathrm{nr}$ & B. henselae, B. clarridgeiae & [208] \\
\hline
\end{tabular}


Table 2 Bartonella spp. clinico-epidemiological studies involving cats in Europe (Continued)

\begin{tabular}{|c|c|c|c|c|c|c|}
\hline \multirow[t]{2}{*}{ Country (area, year) } & \multirow{2}{*}{$\begin{array}{l}\text { Total no. of animals } \\
\text { studied (lifestyle) }\end{array}$} & \multicolumn{3}{|c|}{ Percentage of positive animals } & \multirow{2}{*}{$\begin{array}{l}\text { Confirmed Bartonella } \\
\text { spp. and type using } \\
\text { molecular methods }\end{array}$} & \multirow[t]{2}{*}{ Reference } \\
\hline & & $\begin{array}{l}\text { Serology (method } \\
\text { or antigen used) }\end{array}$ & $\begin{array}{l}\text { Blood } \\
\text { PCR }\end{array}$ & $\begin{array}{l}\text { Blood } \\
\text { culture }\end{array}$ & & \\
\hline Portugal (Lisbon, Evora, 2009) & $\begin{array}{l}51 \text { (client-owned, } \\
\text { shelter and stray) }\end{array}$ & 64.9 & 67.7 & $\mathrm{nr}$ & B. henselae & [209] \\
\hline Portugal (1995) & $14(\mathrm{nr})$ & 14.3 (B. quintana); 6.7 & $\mathrm{nr}$ & $\mathrm{nr}$ & na & [210] \\
\hline Portugal (2014) & $\begin{array}{l}649 \text { (stray and } \\
\text { client-owned) }\end{array}$ & $\mathrm{nr}$ & 2.9 & $\mathrm{nr}$ & Bartonella spp. & [211] \\
\hline $\begin{array}{l}\text { Spain (Barcelona, Tarragona, Mallorca, } \\
\text { 2005) }\end{array}$ & 115 (client-owned) & 29.6 & 7.0 & $\mathrm{nr}$ & B. henselae & {$[212]$} \\
\hline $\begin{array}{l}\text { Spain (Barcelona, Tarragona, } \\
\text { Mallorca, 2006) }\end{array}$ & 168 (client-owned) & 71.4 & 17.0 & $\mathrm{nr}$ & B. henselae, B. clarridgeiae & {$[64]$} \\
\hline Spain (Barcelona, 2008) & 100 (client-owned) & $\mathrm{nr}$ & 1 & $\mathrm{nr}$ & B. clarridgeiae & [213] \\
\hline Spain (Madrid, 2012) & $\begin{array}{l}680 \text { (client-owned } \\
\text { and stray) }\end{array}$ & 24.7 & 0.3 & $\mathrm{nr}$ & B. henselae & {$[127]$} \\
\hline Spain (Rioja, Catalonia, 2013) & $\begin{array}{l}147 \text { (stray and } \\
\text { client-owned) }\end{array}$ & $\mathrm{nr}$ & 32 & $\mathrm{nr}$ & B. henselae, B. clarridgeiae & [214] \\
\hline Spain (multiple locations, 2015) & 86 (client-owned) & 50 & $\mathrm{nr}$ & $\mathrm{nr}$ & B. henselae & {$[215]$} \\
\hline Spain (Zaragoza, 2016) & 47 (stray and shelter) & $\mathrm{nr}$ & 38.29 & $\mathrm{nr}$ & B. henselae & {$[216]$} \\
\hline Spain (Catalonia, 2016) & 116 (shelter) & 35.3 (ELISA) & 22.4 & $\mathrm{nr}$ & B. henselae, B. clarridgeiae & {$[217]$} \\
\hline Scotland (2011) & $\begin{array}{l}52 \text { (client-owned } \\
\text { and stray) }\end{array}$ & 15.4 (ELISA) & 5.8 & $\mathrm{nr}$ & B. henselae & [218] \\
\hline $\begin{array}{l}\text { Sweden (different locations, } \\
\text { 2002) }\end{array}$ & $292(\mathrm{nr})$ & $\begin{array}{l}0 \text { (B. quintana); } 25 \text { ( } B . \\
\text { elizabethae); } 1 \text { (B. henselae) }\end{array}$ & $\mathrm{nr}$ & $\mathrm{nr}$ & na & [219] \\
\hline Sweden (Stockholm, 2003) & 91 (client-owned) & $\mathrm{nr}$ & $\mathrm{nr}$ & 2.2 & B. henselae type II & [220] \\
\hline $\begin{array}{l}\text { Switzerland (Tessin, northern, } \\
\text { 1997) }\end{array}$ & $\begin{array}{l}728 \text { (client-owned } \\
\text { and shelter) }\end{array}$ & 8.3 & $\mathrm{nr}$ & $\mathrm{nr}$ & na & [150] \\
\hline UK (Bristol, 2002) & $360(\mathrm{nr})$ & $\mathrm{nr}$ & $\mathrm{nr}$ & 9.4 & B. henselae types I and II & [221] \\
\hline UK (2000) & $\begin{array}{l}148 \text { (stray and } \\
\text { client-owned) }\end{array}$ & 41.2 (ELISA) & $\mathrm{nr}$ & $\mathrm{nr}$ & na & {$[72]$} \\
\hline
\end{tabular}

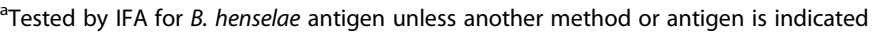

Abbreviations: ELISA enzyme-linked immunosorbent assay, IFA indirect immunofluorescence assay, na not applicable, nr not reported

(73.0\%), as well as a high molecular prevalence $(7.9 \%)$ using Bartonella alpha proteobacteria growth medium (BAPGM)/PCR [104]. Interestingly, the lowest IFA seroreactivity was found against B. quintana antigen (11.2\%) and the highest, against $B$. vinsonii berkhoffii genotype III antigen (56\%). Infection with B. henselae, B. vinsonii berkhoffii genotypes I and III, and B. quintana DNA was documented [104]. In a previous study carried out in Spain using a commercial enzyme-linked immunosorbent assay (ELISA) kit B. henselae seroprevalence in cat owners, and blood donors was 28.9 and 5.9\%, respectively [103]. These lower percentages most likely reflect differences in the antigens used, and exposure risks among the study populations. It is relevant to remark that veterinary personnel have a major exposure risk compared to the general population [104].

\section{Infection and pathogenesis}

In animal models, mainly cat and mouse, after initial inoculation the infection cycle of Bartonella spp. is initiated by colonization of the still enigmatic primary niche where the bacteria reside, persist and are periodically seeded into the bloodstream to cause the typical relapsing Bartonella spp. bacteremia [105]. Endothelial cells, lymph nodes, liver, spleen, kidney, dermis and the bone marrow are some of the proposed niches where Bartonella spp. have been isolated from mammals [106112]. Bartonella henselae has been shown to infect erythrocytes, endothelial cells, macrophages, microglial cells and even human CD $34^{+}$progenitor cells [113116]. In a recent study, Bartonella tribocorum subcutaneous inoculated in rats led to bloodstream invasion through the lymphatic circulation [110], a finding that may have clinical implications for diseases such as chylothorax.

Bartonella tribocorum was able to resist macrophage phagocytosis and to inhibit pyroptosis at an early stage of infection [110]. Endothelial cells are an important target cell type in probably all mammals, including humans incidentally infected by zoonotic species [117]. The 
Table 3 Bartonella spp. clinico-epidemiological studies performed in European dogs

\begin{tabular}{|c|c|c|c|c|c|}
\hline \multirow[t]{2}{*}{ Country (area, year) } & \multirow[t]{2}{*}{$\begin{array}{l}\text { Total no. of animals studied } \\
\text { (lifestyle) }\end{array}$} & \multicolumn{2}{|l|}{$\begin{array}{l}\text { Percentage of positive } \\
\text { animals }^{\mathrm{a}}\end{array}$} & \multirow{2}{*}{$\begin{array}{l}\text { Confirmed Bartonella spp. } \\
\text { and type using molecular } \\
\text { methods }\end{array}$} & \multirow[t]{2}{*}{ Reference } \\
\hline & & $\begin{array}{l}\text { Serology (method or } \\
\text { antigen used) })^{b}\end{array}$ & $\begin{array}{l}\text { Blood } \\
\text { PCR }\end{array}$ & & \\
\hline Albania (Tirana, 2009) & 30 (stray) & 0 (ELISA) & 0 & na & [222] \\
\hline Finland (southern, 2014) & $\begin{array}{l}390 \text { (client-owned and } \\
\text { hunting) }\end{array}$ & $\mathrm{nr}$ & 0 & na & [223] \\
\hline Greece (Thessaloniki, 2009) & 50 (client-owned sick) & $\mathrm{nr}$ & 4 & $\begin{array}{l}\text { B. rochalimae, Bartonella strain } \\
\text { HMD }\end{array}$ & [32] \\
\hline Italy (Sassari, 2007) & 58 (shelter, client-owned) & 28.3 & $\mathrm{nr}$ & na & [199] \\
\hline Italy (Bologna, 2007) & 381 (client-owned) & 6 & $\mathrm{nr}$ & na & [224] \\
\hline Italy (Basilicata, Ginosa, 2009) & 60 (shelter and client-owned) & $\begin{array}{l}\text { 6.6; } 1.7 \text { (B. vinsonii } \\
\text { berkhoffii) }\end{array}$ & 11.6 & $\begin{array}{l}\text { B. henselae, B. vinsonii berkhoffii } \\
\text { types I and II, Bartonella strain } \\
\text { HMD }\end{array}$ & [32] \\
\hline Italy (Sardinia, 2009) & $190(\mathrm{nr})$ & 9.5 & 0 & na & [73] \\
\hline Italy (Aeolian Islands, 2017) & 263 (client-owned) & $\mathrm{nr}$ & 0 & na & [205] \\
\hline Poland (Warsaw, 2007) & $54(n r)$ & $\begin{array}{l}\text { 5.0; } 5.5 \text { (B. vinsonii } \\
\text { berkhoffii) }\end{array}$ & 10.2 & B. henselae, B. vinsonii berkhoffii & [208] \\
\hline Poland (northwestern, 2011) & $\begin{array}{l}242 \text { (client-owned and } \\
\text { shelter) }\end{array}$ & $\mathrm{nr}$ & 0.3 & Bartonella spp. & [225] \\
\hline Portugal (southern, 2014) & 1010 (client-owned and stray) & $\mathrm{nr}$ & 0 & na & [211] \\
\hline Spain (northern, 2006) & 466 (client-owned) & $\begin{array}{l}\text { 16.8; } 1.1 \text { (B. vinsonii } \\
\text { berkhofii) }\end{array}$ & $\mathrm{nr}$ & na & [74] \\
\hline Spain (Barcelona, 2009) & 153 (nr) & $\mathrm{nr}$ & 0 & na & [226] \\
\hline \multirow[t]{2}{*}{ Spain (north-west, 2018) } & $\begin{array}{l}61 \text { (client-owned Leishmania } \\
\text { infected sick dogs); }\end{array}$ & 40 & $\mathrm{nr}$ & na & [227] \\
\hline & 16 (client-owned healthy) & 21 & & & \\
\hline $\begin{array}{l}\text { Spain (north-west, north-east, south-east, } \\
\text { 2018) }\end{array}$ & $\begin{array}{l}30 \text { (client-owned dogs with } \\
\text { culture negative endocarditis) }\end{array}$ & $\mathrm{nr}$ & $26.6^{c}$ & $\begin{array}{l}\text { B. rochalimae, B. vinsonii } \\
\text { berkhoffii, B. koehlerae }\end{array}$ & [136] \\
\hline Spain (north-east, 2018) & $\begin{array}{l}68 \text { (client-owned dogs with } \\
\text { pericardial effusion) }\end{array}$ & $\mathrm{nr}$ & $0^{d}$ & na & [228] \\
\hline UK (2000) & 100 (client-owned) & 3 (ELISA) & $\mathrm{nr}$ & na & [72] \\
\hline UK (Bristol, 2002) & $211(n r)$ & $\mathrm{nr}$ & $\mathrm{nr}$ & na & [221] \\
\hline
\end{tabular}

alood culture was not performed in any of the listed studies with the exception of one study performed in Bristol that did not isolate Bartonella in dogs studied [221]

${ }^{\mathrm{b}}$ Tested by IFA for $B$. henselae antigen unless another method or antigen is indicated

'Samples were from cardiac valve tissue and blood

dSamples were from pericardial effusion and blood

Abbreviations: ELISA enzyme-linked immunosorbent assay, IFA indirect immunofluorescence assay, na not applicable, nr not reported

tropism of Bartonella spp. for endothelial cells in conjunction with their proximity to the bloodstream suggest that endothelial cells are an important constituent of the primary niche [118]. In mammalian reservoir hosts, Bartonella spp. infection is characterized by chronic intraerythrocytic bacteremia whereas in accidental hosts the bacteria are less frequently documented in association with intraerythrocytic bacteremia, potentially due to a very low-level infection of erythrocytes $[105,119]$. Bartonella spp. are able to colonize endothelial cells in both, accidental and reservoir hosts [120]. The endothelial or vascular niche provides the bacterium with a means of seeding the blood with organisms on a sporadic basis, potentially contributing to infection of $\mathrm{CD} 34^{+}$progenitor cells in the bone marrow, as well as circulating erythrocytes and monocytes [16].

In dogs, B. vinsonii berkhoffii can induce vascular endothelial growth factor (VEGF) endothelial cell proliferations, as reported for $B$. bacilliformis, $B$. henselae and $B$. quintana in human patients [121] leading to vascular tumor formation [118] and vasoproliferation, particularly in patients with human immunodeficiency virus (HIV) or therapeutic suppression of the immune system [121]. There is in vitro evidence that B. vinsonii berkhoffii genotypes I, II and III are capable of inducing activation of hypoxia inducible factor-1 and production of VEGF, thereby providing mechanistic evidence as to how these bacteria could contribute to the development of 


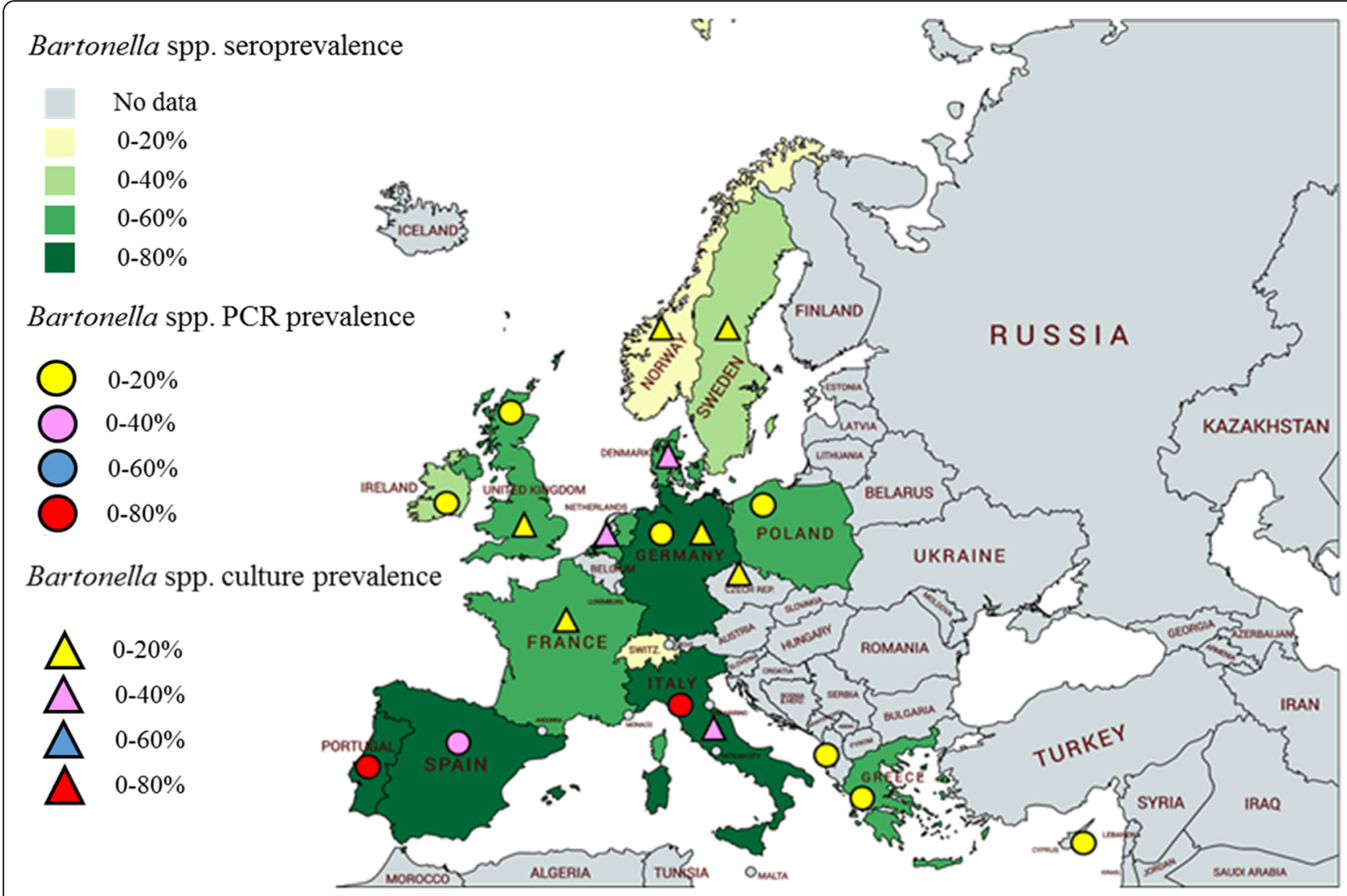

Fig. 1 Geographical distribution maps depicting Bartonella serological, molecular and culture prevalences in cats from European countries. Information provided based on clinico-epidemiological studies reported in Table 2. Created with mapchart.net

vasoproliferative lesions [121]. For this reason, infection with one or more Bartonella spp. may contribute to the pathogenesis of systemic reactive angioendotheliomatosis and hemangiopericytomas in animals [14, 122]. In human patients, activation of hypoxia inducible factor-1 and production of VEGF have been reported for B. bacilliformis, $B$. henselae and B. quintana [121] leading to vascular tumor formation [118] and vasoproliferation, particularly in patients with HIV or therapeutic suppression of the immune system [121]. Moreover, in humans, Bartonella spp. infections range from low to no morbidity (e.g. reactive, suppurative, or granulomatous lymphoid response in immunocompetent individuals), to occasional mortality (e.g. $B$. quintana infection), to substantial mortality in Peru due to the severe hemolytic anemia associated with $B$. bacilliformis [123].

\section{Clinical signs and laboratory abnormalities}

The spectrum of disease manifestations associated with Bartonella spp. infections continues to expand, yet remains incompletely characterized in many domestic and wild animals [16]. Although most acute Bartonella infections are probably self-limiting, persistent infections appear to be associated with a wide variety of clinical signs and pathological abnormalities in cats, dogs, and humans. Bartonella infections manifest from subclinical bacteremia (e.g. healthy animal and human blood donors) to encephalitis, fever of unknown origin, lymphadenomegaly, endocarditis and myocarditis, ocular disease (neuroretinitis, uveitis), skin inflammation and many other less common disease manifestations [124]. Some factors that could influence the appearance of disease manifestations include virulence differences among Bartonella spp. and strains, mode of transmission, differences in the host immune response, concurrent infectious or non-infectious diseases, immunosuppression and malnutrition $[16,125]$.

In the context of comparative medicine, One Health and pet ownership, $B$. henselae, B. koehlerae and B. vinsonii berkhoffii are the three Bartonella spp. most frequently associated with pathology in cats, dogs and humans. As reservoir host for B. henselae and B. koehlerae, cats can be sub clinically infected for months and even years [54]. However, more virulent strains of these species, as well as other Bartonella spp. for which cats are accidental hosts, appear to result in enhanced pathogenicity (Table 6). Furthermore, immunosuppressive viral infections like feline leukemia virus (FeLV) may predispose to $B$. henselae infection or 


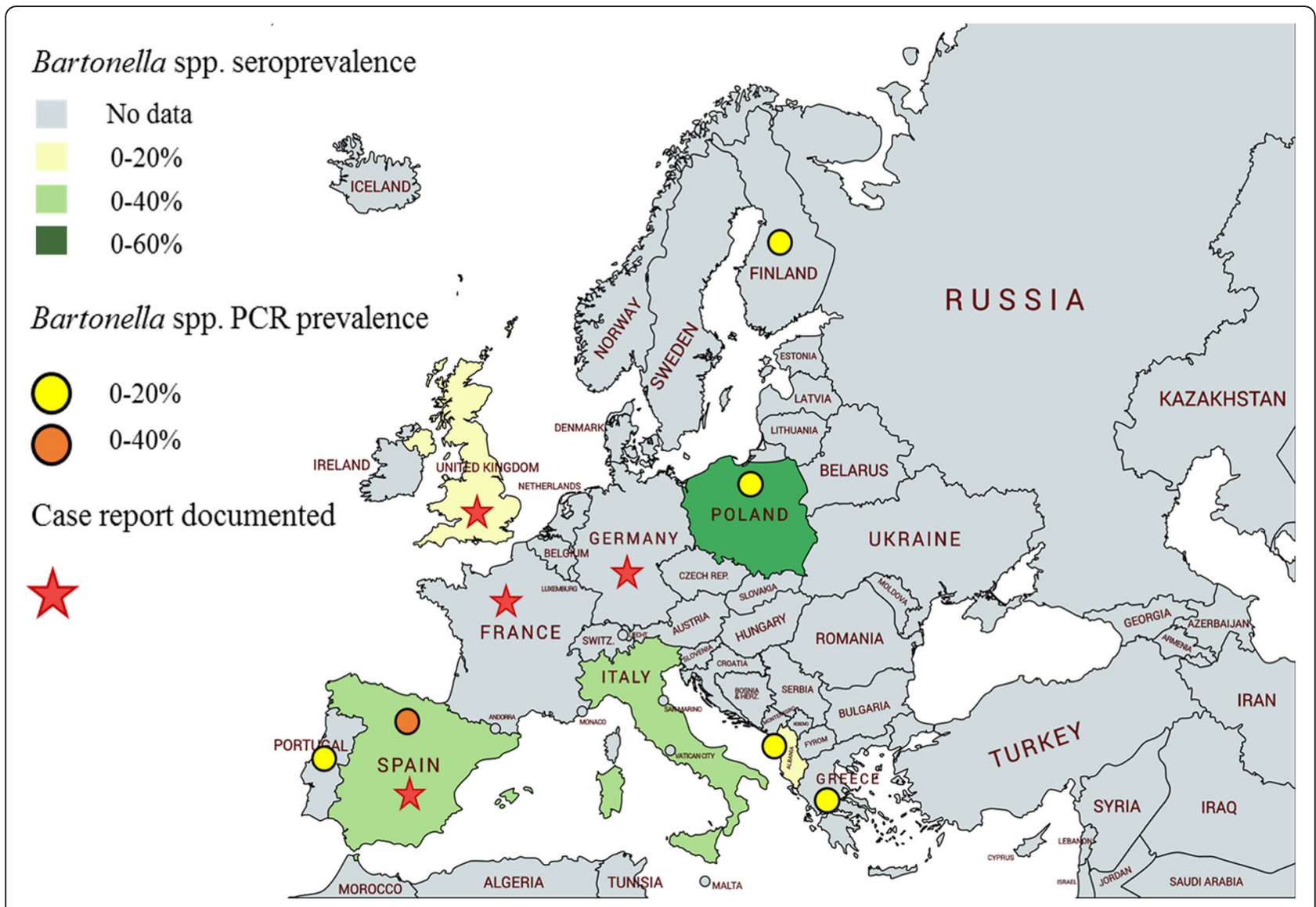

Fig. 2 Geographical distribution maps depicting Bartonella serological and molecular prevalences in dogs from European countries as well as documented case reports. Information provided based on clinico-epidemiological studies reported in Table 3. Created with mapchart.net

persistence in cats [126] (Table 6). Despite long-standing bloodstream infection in cats, complete blood count, serum biochemical profiles and urinalysis findings are frequently normal; however, laboratory abnormalities reported with some frequency in sick cats include anemia, eosinophilia, hyperproteinemia, hyperglobulinemia, neutropenia and thrombocytopenia [127]. In cats experimentally infected with $B$. henselae by blood transfusion, histopathological lesions revealed peripheral lymph node hyperplasia, splenic follicular hyperplasia, lymphocytic cholangitis/pericholangitis, lymphocytic hepatitis, lymphoplasmacytic myocarditis and interstitial lymphocytic nephritis [112]. These indicators of chronic inflammation support the need for long-term studies to determine if cats (or other animals) suffer biological consequences for long-standing infection with one or more Bartonella spp.

Currently, dogs appear to be an accidental rather than reservoir host for $B$. henselae, which is supported by the fact that this is the most frequently documented Bartonella spp. detected in sick dogs [128]. Bartonella henselae DNA was also the predominant Bartonella spp. amplified and sequenced from dogs with splenic hemangiosarcomas [129]. To date, $B$. henselae is the only Bartonella spp. associated with peliosis hepatis in dogs and humans [130,131]. Bartonella henselae has been associated with other disease manifestations in dogs (Table 6) such as pyogranulomatous lymphadenitis, hepatitis and pulmonary nodules, dermatitis, panniculitis and endocarditis [92, 93, 99, 132]. In humans, $B$. henselae causes cutaneous vasoproliferative lesions (bacillary angiomatosis) and parenchymal vasoproliferative lesions of the liver, spleen (bacillary peliosis), and less frequently other tissues, particularly in immunosuppressed individuals including transplant recipients, and HIV and cancer patients $[14,133]$ (Table 6).

Bartonella vinsonii berkhoffii was first isolated from a dog with endocarditis in 1993 [87]. In dogs, B. vinsonii berkhoffii infection has been associated with endocarditis, arrhythmias, myocarditis, granulomatous lymphadenitis and granulomatous rhinitis. Clinical cases of $B$. vinsonii berkhoffii infection in cats and humans have been rarely described in the literature and clinical findings are summarized in Table 6. Current studies indicate Bartonella spp. infections appear to be more 
Table 4 Summary of main clinico-epidemiological studies carried out in cats in continents other than Europe

\begin{tabular}{|c|c|c|c|c|c|}
\hline Continent & Area or country & $\begin{array}{l}\text { Bartonella spp. } \\
\text { seroprevalence (\%) }\end{array}$ & $\begin{array}{l}\mathrm{PCR} / \text { Culture } \\
\text { prevalence (\%) }\end{array}$ & Confirmed Bartonella spp. and type & Reference \\
\hline \multirow[t]{3}{*}{ Africa } & Eastern & 11 & $\mathrm{nf}$ & $\mathrm{nf}$ & [229] \\
\hline & Northern & $15.0-59.6$ & $\begin{array}{l}\text { PCR: } 0.9-23.5 \\
\text { Culture: } 17.0\end{array}$ & B. clarridgeiae, B. henselae & [230-233] \\
\hline & Southern & $21.0-24.0$ & PCR: 7.8 & B. clarridgeiae, B. henselae & [234-236] \\
\hline \multirow[t]{6}{*}{ Asia } & China & nf & $\begin{array}{l}\text { PCR: } 10.5-21.5 ; \\
\text { Culture: } 5.8-18.6\end{array}$ & B. clarridgeiae, B. henselae & [237] \\
\hline & Japan & 8.8 & $\begin{array}{l}\text { PCR: 4.6; } \\
\text { Culture: } 2.0-20.0\end{array}$ & B. clarridgeiae, B. henselae & [238-240] \\
\hline & Korea & $\mathrm{nf}$ & PCR: 41.8-44.1 & B. clarridgeiae, B. henselae & [241] \\
\hline & Middle East & $1.2-39.5$ & $\begin{array}{l}\text { PCR: } 9.4 ; \\
\text { Culture: } 4.3-9.4\end{array}$ & $\begin{array}{l}\text { B. clarridgeiae, B. henselae type I, } \\
\text { B. koehlerae }\end{array}$ & [242-246] \\
\hline & Philippines & $62.6-68.0$ & Culture: 61.0 & B. clarridgeiae, B. henselae & [247] \\
\hline & Thailand & $\mathrm{nf}$ & Culture: $12.8-50.0$ & $\begin{array}{l}\text { B. clarridgeiae, B. henselae types I and } \\
\|\end{array}$ & [248] \\
\hline \multirow[t]{3}{*}{ Australia } & Eastern & 37 & PCR: 26.2 & B. clarridgeiae, B. henselae & [249] \\
\hline & South New Wales (Sydney) & nf & $\begin{array}{l}\text { Culture and PCR: } \\
35.0\end{array}$ & B. henselae & [250] \\
\hline & $\begin{array}{l}\text { Western and Dirk Hartog and } \\
\text { Christmas islands }\end{array}$ & $\mathrm{nf}$ & PCR: 0-5.2 & B. henselae, B. koehlerae & {$[250,251]$} \\
\hline \multirow{3}{*}{$\begin{array}{l}\text { North } \\
\text { America }\end{array}$} & Centre & $0-45.0$ & $\mathrm{nf}$ & $\mathrm{nf}$ & [252] \\
\hline & East & $10.0-85.2$ & PCR: 0-62.5 & $\begin{array}{l}\text { B. clarridgeiae, B. henselae types I and } \\
\text { II, B. koehlerae }\end{array}$ & $\begin{array}{l}{[243,252-} \\
257]\end{array}$ \\
\hline & West & $0-26.2$ & $\begin{array}{l}\text { PCR: } 27.0-27.7 ; \\
\text { Culture: } 32.8\end{array}$ & $\begin{array}{l}\text { B. clarridgeiae, B. henselae types I and } \\
\text { II, B. koehlerae }\end{array}$ & $\begin{array}{l}{[252,258,} \\
259]\end{array}$ \\
\hline \multirow{5}{*}{$\begin{array}{l}\text { South } \\
\text { America }\end{array}$} & Argentina & $\mathrm{nf}$ & PCR: 17.0 & B. clarridgeiae, B. henselae & {$[260]$} \\
\hline & Brazil & $15-68$ & $\begin{array}{l}\text { PCR: } 4.5-97.0 ; \\
\text { Culture: } 45.5\end{array}$ & B. clarridgeiae, B. henselae & {$[261-264]$} \\
\hline & Chile & $5.6-8.0$ & $\begin{array}{l}\text { PCR: 18.1; } \\
\text { Culture: } 41\end{array}$ & B. clarridgeiae, B. henselae, B. koehlerae & {$[265,266]$} \\
\hline & Galapagos islands & 75.0 & PCR: 59.0 & B. clarridgeiae, B. henselae & {$[267]$} \\
\hline & Guatemala & $\mathrm{nf}$ & $\begin{array}{l}\text { PCR: } 33.8 ; \\
\text { Culture } 8.2\end{array}$ & B. clarridgeiae, B. henselae & [268] \\
\hline
\end{tabular}

Abbreviations: $P C R$ polymerase chain reaction, $n f$ not found

pathogenic in dogs and humans than in cats, potentially reflecting differences in host evolutionary adaptations to these vector-borne organisms.

To date, few cases of canine bartonellosis have been reported from Europe (Fig. 2) or other continents when compared with the USA, and the clinical findings match those described in dogs from the USA. Bartonella-associated inflammatory cardiomyopathy was described in a dog from Italy [95]. Bartonella infection in association with panniculitis, polyarthritis and meningitis was reported in a dog from England [75]. In France, B. henselae was amplified from blood of a dog with fever of unknown origin and granulomatous lymphadenitis [134] as well as from saliva in a subclinical German dog owned by a human patient suffering angioedema due to B. henselae [135]. In Spain, B. koehlerae DNA was amplified from blood and mitral valve tissue of a dog with infective endocarditis [30] and B. rochalimae, B. vinsonii berkhoffii and $B$. koehlerae were detected by PCR in valve tissue or blood from eight out of 30 (26.6\%) dogs with blood culture-negative endocarditis [136]. In another study seroreactivity to $B$. henselae was detected in a dog with a monoclonal gammopathy and Bartonella species DNA was amplified from splenic tissue [98].

\section{Diagnosis and identification methods}

Accurate diagnosis of Bartonella infections remains challenging. Currently there is no diagnostic technique for which a negative result assures the absence of infection. The most frequently used techniques for the detection of acute and chronic infections are specialized microbiological culture techniques, polymerase chain reaction (PCR), immunohistochemistry (IHC) and serology [137]. 
Table 5 Summary of main clinico-epidemiological studies carried out in dogs in continents other than Europe

\begin{tabular}{|c|c|c|c|c|c|}
\hline Continent & Area or country & $\begin{array}{l}\text { Bartonella spp. } \\
\text { seroprevalence (\%) }\end{array}$ & $\begin{array}{l}\text { PCR / culture } \\
\text { prevalence (\%) }\end{array}$ & $\begin{array}{l}\text { Confirmed Bartonella spp. } \\
\text { and type }\end{array}$ & Reference \\
\hline \multirow[t]{5}{*}{ Africa } & East & $\mathrm{nf}$ & PCR: 0 & nf & [269] \\
\hline & Central & $\mathrm{nf}$ & PCR: 2.3 & B. clarridgeiae, B. henselae & [27] \\
\hline & North & $19.5-47.4$ & PCR: $0.85-37.1$ & $\begin{array}{l}\text { B. clarridgeiae, B. elizabethae, } B \text {. } \\
\text { henselae, B. rochalimae, B. vinsonii } \\
\text { berkhoffii }\end{array}$ & {$[230,270-272]$} \\
\hline & South & 14 & PCR: 0-9.0; Culture: 0 & B. henselae & {$[233,273,274]$} \\
\hline & West & $\mathrm{nf}$ & PCR: 0 & nf & [275] \\
\hline \multirow[t]{5}{*}{ Asia } & Middle East & $6.6-47.4$ & Culture and PCR: 9.2-37.1 & $\begin{array}{l}\text { "Candidatus Bartonella merieuxii", } \\
\text { B. vinsonii berkhoffii (type III in } \\
\text { one study) }\end{array}$ & {$[276-278]$} \\
\hline & South Korea & $\mathrm{nf}$ & PCR: 0-29.6 & B. clarridgeiae, B. henselae & {$[241,279,280]$} \\
\hline & Sri Lanka & 5.1 & PCR: 3.38 & Bartonella strain HMD & [281] \\
\hline & Thailand & 38 & $\begin{array}{l}\text { PCR: 1.8; Culture and PCR: } \\
0.3-31.3\end{array}$ & $\begin{array}{l}\text { B. clarridgeiae, B. elizabethae, } B . \\
\text { grahamii, B. quintana, B. taylorii, } \\
\text { B. vinsonii arupensis }\end{array}$ & {$[40,282-284]$} \\
\hline & Vietnam & 0 & PCR: 0 & nf & [281] \\
\hline Australia & $\begin{array}{l}\text { New South Wales and Northern } \\
\text { Territory }\end{array}$ & 0 & Culture and PCR: 0 & nf & [285] \\
\hline \multirow{3}{*}{$\begin{array}{l}\text { North } \\
\text { America }\end{array}$} & Centre & $0-20$ & $\mathrm{nf}$ & nf & {$[69,286]$} \\
\hline & East & $0-49$ & PCR: 9.2; Culture: 52.5 & $\begin{array}{l}\text { B. bovis, B. henselae, B. koehlerae, } \\
\text { B. vinsonii berkhoffiii, B. volans-like }\end{array}$ & $\begin{array}{l}{[68,69,128,} \\
286]\end{array}$ \\
\hline & West & $0-29$ & PCR: 0-1.7; Culture: 2.2 & $\begin{array}{l}\text { B. clarridgeiae-like, B. vinsonii } \\
\text { berkhoffii }\end{array}$ & {$[69,286-288]$} \\
\hline \multirow{6}{*}{$\begin{array}{l}\text { South } \\
\text { America }\end{array}$} & Argentina & $\mathrm{nf}$ & PCR: 3 & B. clarridgeiae & [260] \\
\hline & Brazil & $1.5-24.8$ & PCR and culture: 1 & B. henselae, B. vinsonii berkhoffii & $\begin{array}{l}{[262,264,281,} \\
289]\end{array}$ \\
\hline & Chile & $\mathrm{nf}$ & PCR: 4.3 & B. henselae, B. vinsonii berkhoffii & [290] \\
\hline & Colombia & 10.1 & PCR: 0.77 & $\begin{array}{l}\text { B. rochalimae, B. vinsonii } \\
\text { berkhoffii }\end{array}$ & [281] \\
\hline & Galapagos Islands & $\mathrm{nf}$ & PCR: 13.6 & $\begin{array}{l}\text { B. clarridgeiae, B. elizabethae, } \\
\text { B. henselae }\end{array}$ & [267] \\
\hline & Peru & $40-62$ & PCR: 10 & $\begin{array}{l}\text { B. rochalimae, B. vinsonii } \\
\text { berkhoffii type III }\end{array}$ & [291] \\
\hline
\end{tabular}

Abbreviations: $P C R$ polymerase chain reaction, $n f$ not found

Specialized culture techniques including lysis centrifugation, cell culture isolation and growth enrichment in insect biochemical composition growth media are the "gold standard" for confirmation of Bartonella infection. Optimal samples for microbiological culture include blood, cerebrospinal fluid [138], joint fluid [81], pathological effusions [138] and tissue biopsies [139]. In reservoir-adapted hosts such as rodents and cats and infrequently in accidental hosts (sick dogs or humans), Bartonella spp. can be cultured successfully with agar plates containing 5\% defibrinated rabbit or sheep blood, that are maintained at $35{ }^{\circ} \mathrm{C}$ in a high humidity chamber with $5 \% \mathrm{CO}_{2}$ concentration. Agar plate isolation requires prolonged incubation times: bacterial colonies may not be visible until 10-56 days after inoculation of the agar plate [140]. Because Bartonella spp. are fastidious, slow-growing bacteria, a negative blood culture or biopsy culture after a long incubation period does not exclude suspected Bartonella infection [141]. Furthermore, the patient can be intermittently bacteremic as documented in feline $B$. henselae experimental infections [59, 112]. Similarly, testing serial blood specimens collected over a 7-day period enhanced microbiological documentation of Bartonella as reported in humans [142]. BAPGM, an optimized insect cell medium, has been used in an enrichment culture platform to enhance the growth of Bartonella spp. prior to attempted subculture bacterial isolation. The BAPGM, prior to PCR testing, has been used to increase sensitivity for documentation of infection, thereby facilitating a diagnosis of bartonellosis in cats, dogs and humans [16]. The BAPGM platform combines enrichment culture of a clinical 
Table 6 Clinical sign, lesions and laboratory abnormalities reported in association with Bartonella infections in cats, dogs and humans

\begin{tabular}{|c|c|c|c|}
\hline \multirow{2}{*}{$\begin{array}{l}\text { Bartonella } \\
\text { spp. }\end{array}$} & \multicolumn{3}{|l|}{ Hosts $^{a}$} \\
\hline & Cats & $\operatorname{Dogs}^{b}$ & Humans \\
\hline B. henselae & $\begin{array}{l}\text { Anemia (El); diaphragmatic myositis } \\
(\mathrm{NI}) ; \text { endocarditis (NI); } \\
\text { endomyocarditis - left ventricular; } \\
\text { endocardial fibrosis complex (NI); } \\
\text { eosinophilia (NI); fever (EI, NI); } \\
\text { hyperglobulinemia (El, NI); lethargy } \\
(\text { (El, NI); lymphadenomegaly (EI); mild } \\
\text { neurological signs (El); } \\
\text { pyogranulomatous myocarditis and } \\
\text { uveitis, conjunctivitis, keratitis and } \\
\text { corneal ulcers (NI); subclinical (EI, NI); } \\
\text { thrombocytopenia (NI) }\end{array}$ & $\begin{array}{l}\text { Endocarditis (NI); eosinophilia (NI); } \\
\text { epistaxis(NI); fever (NI); granulomatous } \\
\text { hepatitis (NI); granulomatous inflammation } \\
\text { (NI); hyperglobulinemia (NI); hyperinsulinemic } \\
\text { hypoglycemia syndrome (NI); ineffective } \\
\text { erythropoiesis (NI); lymphadenomegaly (NI); } \\
\text { monoclonal gammopathy (NI); peliosis hepatis } \\
\text { (NI); subclinical (El, NI); thrombocytopenia (NI); } \\
\text { vasoproliferative lesions (NI) }\end{array}$ & $\begin{array}{l}\text { Arthralgia; arthritis; bacillary angiomatosis; } \\
\text { CSD; endocarditis; erythema; granulomatous } \\
\text { hepatis; neuroretinitis; peliosis hepatis; } \\
\text { pulmonary nodules; uveitis; vasoproliferative } \\
\text { tumors }\end{array}$ \\
\hline $\begin{array}{l}\text { B. vinsonii } \\
\text { berkhoffii }\end{array}$ & $\begin{array}{l}\text { Endocardial fibrosis complex (NI); } \\
\text { endomyocarditis - left ventricular; } \\
\text { osteomyelitis (NI) }\end{array}$ & $\begin{array}{l}\text { Anemia (NI); arrhythmias (NI); endocarditis (NI); } \\
\text { epistaxis (NI); fever (NI); granulomatous } \\
\text { lymphadenitis (NI); hemangiosarcoma (NI); } \\
\text { myocarditis (NI); polyarthritis (NI); splenomegaly } \\
\text { (NI); subclinical (El, NI); thrombocytopenia (NI); } \\
\text { uveitis (NI) }\end{array}$ & Endocarditis \\
\hline B. clarridgeiae & NCR or subclinical & Endocarditis (NI); hepatic disease (NI) & CSD \\
\hline B. quintana & NCR or subclinical & Endocarditis (NI); subclinical (NI) & $\begin{array}{l}\text { Bacillary angiomatosis; endocarditis; fever; } \\
\text { neuroretinitis; uveitis }\end{array}$ \\
\hline B. koehlerae & $\begin{array}{l}\text { Endomyocarditis - left ventricular; } \\
\text { endocardial fibrosis complex }\end{array}$ & $\begin{array}{l}\text { Endocarditis (NI); hyperinsulinemic hypoglycemia } \\
\text { syndrome (NI); splenic disease (NI) }\end{array}$ & Endocarditis \\
\hline B. rochalimae & NCR or subclinical (EI) & Endocarditis (NI); subclinical (El) & Fever; splenomegaly \\
\hline B. washoensis & NCR or subclinical & Endocarditis (NI) & Fever; myocarditis \\
\hline
\end{tabular}

aDetails included in Table 6 are provided in $[20-22,29,30,39,70,91,92,96,98,99,112,127,132,136,154,160,168-170,289,292-305]$

${ }^{b}$ Pathology reported in dogs to date is mainly due to natural infection only

Abbreviations: CSD cat scratch disease, El experimental infection, $N I$ natural infection, $N C R$ not clearly related (the reports did not completely prove the direct relation between the clinical findings and the Bartonella infection or the animals had subclinical infection)

specimen in the liquid growth medium for a minimum of 7 days, followed by a highly sensitive PCR assay designed to amplify all known Bartonella spp. [142]. When testing cat blood samples, $B$. henselae and B. clarridgeiae can often be isolated effectively using agar plates; however, isolation of the same Bartonella spp. from sick cats, dogs, horses or human blood samples using an identical isolation approach lacks sensitivity. Although additional optimization of Bartonella spp. isolation is needed, the introduction of BAPGM has facilitated the successful isolation of B. henselae and several other Bartonella spp. from dog, horse, human and wildlife blood samples [142-145].

The most employed tissue for Bartonella detection by PCR is peripheral blood. However, PCR for Bartonella spp. detection and characterization can be also performed after DNA extraction from cerebrospinal fluid, joint fluid, bacterial cultures, oral swabs, lymph node or other tissue samples or aspirates depending on each individual clinical case. To avoid DNA denaturation by formalin fixation, it is advisable to store tissues for future testing or submit fresh or fresh frozen specimens for PCR amplification of Bartonella DNA. Once the PCR is positive for the genus Bartonella, the species can be determined using species-specific primers or optimally by DNA sequencing [146-149].

Seroconversion can be used to confirm acute Bartonella spp. infection by documenting a four-fold rise in antibody titer over a 2-3-week period [16]. To date, there has been minimal use of serology or other diagnostic modalities for testing cats or dogs with acute onset illness [56]. Serological tests used to detect antibodies include IFA, ELISA and western immunoblot [56]. Serological tests appear to have good specificity and can be used to confirm prior or ongoing infection, but due to poor sensitivity, serology is of more limited value for predicting bacteremia in dogs and potentially sick cats $[69,150]$. In cats, high antibody titers often correlate with positive blood cultures or PCR amplification of Bartonella DNA directly from blood [140]. Alternatively, the inability to detect $B$. henselae antibodies appears to be predictive of the absence of bacteremia in healthy cats [151], but similar to dogs and humans, there are sick bacteremic cats that do not have detectable Bartonella spp. antibodies, for reasons that remain unclear [128]. It is important to note that only $50 \%$ of dogs infected with B. vinsonii berkhoffii and $25 \%$ of dogs infected with $B$. henselae have Bartonella specific IFA 
antibody reactivity to the respective organism. PCR amplification of organism-specific gene fragments is often diagnostically useful for Bartonella cases in which culture and serology results are negative [128].

Studies to date indicate that inflammatory lesions (e.g. pyogranulomatous inflammation) can be severe; however, few organisms are normally visualized [111]. Therefore, stains and techniques to better visualize bacteria in histological specimens are available such as Warthin-Starry staining or immunohistochemistry. Bartonella spp. as well as other bacteria such as Helicobacter pylori or Legionella pneumophila can be visualized in biopsied tissues using Warthin-Starry staining [152]. For this reason, other techniques like Bartonella immunohistochemistry, fluorescent in situ hybridization (FISH) and PCR can be used to confirm that the bacteria observed by Warthin-Starry staining of histopathological lesions are Bartonella spp. [153].

Immunohistochemistry, including confocal immunohistochemistry, has been used for the detection of Bartonella spp. in cat, dog and human tissues [38, 94, 153-157]. The principal advantage of immunohistochemistry over other antigen detection techniques is the ability to identify the organism directly in the tissue samples such as cardiac valves or lymphoid organs and thus more effectively establish correlations between antigen localization and histopathological lesions [158]. An immunoassay using two specific in-house B. henselae monoclonal antibodies (MAb) documented the intra-erythrocytic localization of this bacterium in three blood culture positive cats. That study concluded that direct fluorescence with a specific MAb is a sensitive, rapid and simple technique which could be useful for detecting Bartonella infections in healthy cats [159].

\section{Clinical decision making in light of diagnostic results}

The definitive diagnosis of bartonellosis in cats, dogs and, based upon more recent literature, humans [62, 104] remains a clinical, microbiological and pathological challenge. Based on the broad spectrum of historical and clinical abnormalities, bartonellosis is often among differential diagnostic considerations for various clinical problems. However, in many clinical situations, bartonellosis is either not considered diagnostically or becomes a diagnosis after exclusion of other compatible disease entities. However, it is important for clinicians to attempt to achieve diagnostic confirmation prior to embarking upon a long duration antibiotic therapy. A positive therapeutic response to antibiotics, in conjunction with seroreactivity or positive culture or PCR results, provides indirect support for a definitive diagnosis of bartonellosis. Prior or ongoing administration of antibiotics and potentially immunosuppressive drugs can adversely affect serological and molecular diagnostic test results $[56,160]$. According to the experience of the authors and current literature, Bartonella infection should be investigated using both serology, culture and/or molecular methods (PCR) in healthy pets when: (i) screening cats and dogs as blood donors [60]; (ii) in pets owned by inmunocompromised persons [161]; (iii) Bartonella infection has been diagnosed or is suspected in a pet owner [162]; and (iv) when there is a history of exposure to fleas, ticks, others arthopods or scratch or bite wound in sick pets [163]. Interpretation of various diagnostic results to guide clinical decision making are summarized in Table 7.

Table 7 Treatment decision based on culture, PCR and serology results in sick animals with suspected Bartonella infection [16, 59, $62,104,112,128]$

\begin{tabular}{|c|c|c|c|c|}
\hline \multicolumn{3}{|c|}{ Diagnostic methods } & \multirow[t]{2}{*}{ Bartonella infection ${ }^{a}$} & \multirow[t]{2}{*}{ Treatment decisions options } \\
\hline Culture & PCR & Serology & & \\
\hline+ & + & + & Confirmed & Treat \\
\hline+ & + & - & Confirmed & Treat \\
\hline+ & - & - & Confirmed & Treat \\
\hline+ & - & + & Confirmed & Treat \\
\hline- & + & + & Confirmed & Treat \\
\hline- & + & - & Confirmed & Treat \\
\hline - & - & + & $\begin{array}{l}\text { Bartonellosis not excluded; Repeat culture and } \\
\text { PCR if the suspicion of clinical bartonellosis remains }\end{array}$ & $\begin{array}{l}\text { Do not treat or treat empirically } \\
\text { if disease progresses. Empirical } \\
\text { treatment should not be routinely } \\
\text { recommended }\end{array}$ \\
\hline- & - & - & $\begin{array}{l}\text { Bartonellosis not excluded; Repeat serology in } \\
2-3 \text { weeks or culture and PCR in a few days if } \\
\text { the suspicion of clinical bartonellosis remains }\end{array}$ & $\begin{array}{l}\text { Do not treat or treat empirically } \\
\text { if disease progresses. Empirical } \\
\text { treatment should not be routinely } \\
\text { recommended }\end{array}$ \\
\hline
\end{tabular}

${ }^{a}$ Despite diagnostic confirmation of bartonellosis in cats and dogs, as listed in the table, vector-borne disease co-infections, co-morbidities and other differential diagnoses should be evaluated in conjunction with or prior to administration of antimicrobial drugs

Key: +, positive; -, negative 


\section{Treatment}

Antimicrobial therapy comprises the primary treatment modality and in most cases a combination of antibiotics is necessary to achieve disease resolution (Table 8). There is no standardized antibiotic protocol for treatment of bartonellosis in cats or dogs [164]. Data from controlled efficacy studies involving naturally-infected cats and dogs are lacking. While many antibiotics are effective in vitro, in vivo efficacy appears to vary among individual patients [25]. Treatments have varied depending upon the predominant tissue location of disease manifestations (e.g. endocard, brain, or blood stream infection).

Most laboratory-based antibiotic treatment studies indicate that complete clearance of Bartonella spp. from cats has not been achieved with antibiotics studied to date (doxycycline, amoxicillin, amoxicillin-clavulanic acid, enrofloxacin, erythromycin and rifampicin) [59, 164-166]. Results of these studies were variable with bacteremia apparently being eliminated in some cats $[167,168]$. Serum antibody titers typically decrease rapidly (3-6 months) and remain below the limits of detection in animals that have a positive treatment response, and have presumably eliminated the infection [2]. Treatment in sick cats is recommended when Bartonella spp. are confirmed diagnostically and compatible disease entities (e.g. endocarditis, encephalitis, myocarditis, fever and uveitis) are suspected or confirmed (Table 8). Because widespread use of antibiotics contributes to antimicrobial resistance among non-targeted bacteria, antibiotic treatment is not routinely recommended for healthy, $B$. henselae bacteremic cats, despite the risk of zoonotic transmission [167]. However, antibiotic treatment of bacteremic healthy cats living in a household with immunocompromised adults or young children is recommended. In these cases, treatment is aimed at decreasing bacterial load, minimizing the risk of additional vector exposure and thus decreasing the risk of transmission among pets or to humans.

An optimal protocol for treatment Bartonella spp. infection in dogs has also not been established. Use of an antibiotic capable of crossing lipid membranes and reaching high intracellular concentrations, such as amoxicillin, azithromycin, doxycycline and enrofloxacin is recommended [168-170]. Macrolides, like azithromycin, are effective but are not recommended as a first line antibiotic due to rapid development of resistance among $B$. henselae strains. Once genetically-mediated (mutation) resistance developed, $B$. henselae isolates were resistant to all macrolides [16]. For dogs with central nervous system involvement, a combination of doxycycline and rifampicin has been used successfully, but the use of rifampicin is not recommended in cats [167]. Aminoglycosides, used to treat human endocarditis, are recommended in conjunction with careful monitoring of renal function during the initial treatment of suspected Bartonella endocarditis or myocarditis in cats and dogs. A combination of doxycycline and amikacin represents a treatment option for Bartonella endocarditis in cats and dogs [16]. For dogs that are reasonably stable starting with one antibiotic (for example doxycycline at $5 \mathrm{mg} / \mathrm{kg}$ every 12 hours) and adding the

Table 8 Reported treatments in cats and dogs

\begin{tabular}{|c|c|c|c|c|}
\hline Host & $\begin{array}{l}\text { Clinical Bartonella spp. manifestations/ } \\
\text { species }\end{array}$ & Treatment & Dose/duration & Reference $^{a}$ \\
\hline \multirow[t]{5}{*}{ Cats } & \multirow[t]{3}{*}{ Bacteremia and uveitis/Bartonella spp. } & Doxycycline + Pradofloxacin & $\begin{array}{l}5 \mathrm{mg} / \mathrm{kg} \text { PO q } 12 \mathrm{~h} / 4-6 \text { weeks }+5 \text { mg/kg PO q } \\
12 \mathrm{~h} / 4-6 \text { weeks }\end{array}$ & {$[167]$} \\
\hline & & Doxycycline & 10 mg/kg PO q 12-24 h/4-6 weeks & {$[170]$} \\
\hline & & Azithromycin & $\begin{array}{l}10 \text { mg/kg PO q 24-48 h/ } 7 \text { days followed by } \\
\text { every other day for 6-12 weeks }\end{array}$ & {$[169]$} \\
\hline & Endocarditis/B. henselae & $\begin{array}{l}\text { Marbofloxacin + } \\
\text { Azithromycin }\end{array}$ & $\begin{array}{l}5 \mathrm{mg} / \mathrm{kg} \text { PO q } 24 \mathrm{~h} / 6 \text { weeks }+10 \mathrm{mg} / \mathrm{kg} \mathrm{PO} \\
\mathrm{q} 24 \mathrm{~h} \text { for } 7 \text { days and then q } 48 \mathrm{~h} / 6 \text { weeks }\end{array}$ & {$[294]$} \\
\hline & $\begin{array}{l}\text { Osteomyelitis and polyarthritis/B. } \\
\text { vinsonii berkhoffii }\end{array}$ & $\begin{array}{l}\text { Amoxicillin-clavulanate }+ \\
\text { Azithromycin }\end{array}$ & $\begin{array}{l}62.5 \mathrm{mg} \text { PO q } 12 \mathrm{~h} / 2 \text { months }+10 \mathrm{mg} / \mathrm{kg} \\
\mathrm{PO} \mathrm{q} 48 \mathrm{~h} / 3 \text { months }\end{array}$ & {$[168]$} \\
\hline \multirow[t]{5}{*}{ Dogs } & $\begin{array}{l}\text { Splenic vasculitis, thrombosis and } \\
\text { infarction/B. henselae }\end{array}$ & $\begin{array}{l}\text { Doxycycline + Trimethoprim- } \\
\text { sulfamethoxazole }\end{array}$ & $\begin{array}{l}5-10 \text { mg/kg PO q } 12 \text { h/4 weeks + } 23 \text { mg/kg, } \\
\text { PO q } 12 \text { h/6 weeks }\end{array}$ & {$[28]$} \\
\hline & \multirow[t]{2}{*}{$\begin{array}{l}\text { Neurological and ocular disorders/ } \\
\text { Bartonella spp. }\end{array}$} & Doxycycline + Enrofloxacin & $\begin{array}{l}5-15 \text { mg/kg PO q } 12 \mathrm{~h}+5 \mathrm{mg} / \mathrm{kg} \text { PO q } 12 \mathrm{~h} \\
/ 4-6 \text { weeks }\end{array}$ & [169] \\
\hline & & Doxycycline + Rifampicin & $\begin{array}{l}5-10 \text { mg/kg PO q } 12+5 \text { mg/kg PO q } 24 \text { h/ 4-6 } \\
\text { weeks }\end{array}$ & \\
\hline & Endocarditis/B. koehlerae & Ampicillin + Enrofloxacin & $\begin{array}{l}22 \mathrm{mg} / \mathrm{kg} \text { PO q } 8 \mathrm{~h}+5 \text { mg/kg PO q 12-24 h } \\
/ 4-6 \text { weeks }\end{array}$ & {$[30]$} \\
\hline & Hemangiopericytoma/B. vinsonii berkhoffii & Enrofloxacin & 5 mg/kg PO q 12 h/4-6 weeks & {$[14]$} \\
\hline
\end{tabular}


second antibiotic 5-7 days later may help to avoid a potential Jarisch-Herxheimer-like reaction that appears to be related to rapid bacterial injury/death. The Jarisch-Herxheimer-like reaction is typically associated with lethargy, fever, occasionally vomiting and commonly occurs in cats and dogs at 4-7 days after starting antibiotics. If a Jarisch-Herxheimer-like reaction occurs, it is not recommended to interrupt or change antibiotics; supportive therapy and anti-inflammatory steroids for a few days may help dogs through this period [167].

General treatment recommendations for feline and canine bartonellosis based upon the literature and the authors' experiences are summarized below:

- Diagnostic confirmation of clinical bartonellosis is recommended or a very high index of suspicion.

- Prolonged treatment periods (4-6 weeks) are recommended to avoid bacterial drug resistance and to achieve disease resolution.

- Antibiotics are currently the mainstay of treatment.

- It is not recommended to use macrolides as the first therapy option.

- Antibiotics combinations with various mechanisms of action, achieving therapeutic drug concentrations within cells and within plasma are needed to eradicate Bartonella infections.

\section{Preventative measures}

As vaccines are not available to prevent infection, flea and tick control are the only successful measures to prevent this vector-borne infection in healthy animals [166], to decrease the dispersion of these bacteria among canine and feline populations, and to decrease the risk of zoonotic pathogen transmission to humans [65]. Cats and dogs should be protected from flea and tick infestations year-round by the regular use of acaricides in the form of collars, spot-on or spray-on or oral formulations [171]. Furthermore, both people and pets should avoid contact with stray dogs and cats. In the context of One Health, the authors support the future development of vaccines to protect pets against infection with $B$. henselae and B. vinsonii berkhoffii and thereby decrease reservoir potential and zoonotic risks.

In households with immunosuppressed persons or young children, if their pets are determined as bacteremic, antibiotic treatment and routine acaricide use are recommended for these pets. When acquiring a new cat or dog, into a household with immunocompromised individuals and children, choosing an adult animal will lower the possibility of acquiring a Bartonella spp. bacteremic pet $[25,65]$.

Blood transfusion has also been identified as a risk factor for the transmission of Bartonella infections. Screening of blood donors for Bartonella infections, should be considered $[37,60]$.

\section{Conclusions}

Based upon the recent and ongoing discovery of novel Bartonella spp. in hosts such as bats [172, 173] and rodents [174], it is likely that additional Bartonella spp., in conjunction with their respective reservoir host and vector, will be described. Furthermore, as Bartonella spp. transmission routes are not fully understood, research efforts should focus on modes of transmission so that appropriate control measures can be implemented to prevent the pathogen transmission between animals and from animals to humans. Bartonella spp. seroprevalence rates in cats and dogs in Europe and other parts of the world do not correspond with the low number of reported clinical cases, especially in dogs, potentially because Bartonella infections are underdiagnosed. The limited number of reported cases of Bartonella spp. infection compromises our collective ability to establish a complete list of clinical conditions or specific pathologies related to this infection. In conclusion, more efforts are needed in both research and clinical settings to characterize the medical importance of Bartonella spp. infections in cats and dogs. Additionally, randomized case control studies are needed to assess treatment efficacy and to establish an optimal protocol for the treatment of chronic bartonellosis in cats, dogs and humans. Efforts to develop safe and effective vaccines are needed to protect pets and their families.

\section{Abbreviations \\ BAPGM: Bartonella alpha proteobacteria growth medium; $\mathrm{CO}_{2}$ : Carbon dioxide; CSD: Cat scratch disease; El: Experimental infection; ELISA: Enzyme- linked immunosorbent assay; FeLV: Feline leukemia virus; FISH: Fluorescent in situ hybridization; HIV: Human immunodeficiency virus; IFA: Indirect immunofluorescence assay; IgG: Immunoglobulin G; \\ IHC: Immunohistochemistry; MAb: Monoclonal antibody; NA: Not applicable; NCR: Not clearly related; NI: Natural infection; NF: not found; nr: Not reported; PCR: Polymerase chain reaction; PO: Oral administration; q: Every; \\ VEGF: Vascular endothelial growth factor}

\section{Acknowledgements}

Open access publication of the paper has been sponsored by Bayer Animal Health (Germany) in the framework of a sponsored research project.

\section{Funding}

Open access publication of the paper has been sponsored by Bayer Animal Health (Germany) in the framework of a sponsored research project.

\section{Availability of data and materials}

Not applicable.

\section{Authors' contributions}

LSG conceived the manuscript. AAF wrote, and EB and LSG edited the first draft. All authors read and approved the final manuscript.

Ethics approval and consent to participate

Not applicable.

Consent for publication

Not applicable.

Competing interests

LSG and AAF declare that they have no competing interests. In conjunction with Dr Sushama Sontakke and North Carolina State University, EBB holds 
U.S. patent no. 7,115,385; Media and Methods for cultivation of microorganisms, which was issued on 3rd October 2006. He is a co-founder, shareholder and Chief Scientific Officer for Galaxy Diagnostics, a company that provides advanced diagnostic testing for the detection of Bartonella species infections.

\section{Publisher's Note}

Springer Nature remains neutral with regard to jurisdictional claims in published maps and institutional affiliations.

\section{Author details}

${ }^{1}$ Departament de Medicina i Cirurgia Animals, Facultat de Veterinària, Universitat Autònoma de Barcelona, 08193 Bellaterra, Spain. ${ }^{2}$ Department of Clinical Sciences and the Comparative Medicine Institute, College of Veterinary Medicine, North Carolina State University, 1060 William Moore Dr, Raleigh, NC 27607, USA.

Received: 27 February 2018 Accepted: 14 October 2018 Published online: 04 December 2018

\section{References}

1. Deng H, Le Rhun D, Buffet J-PR, Cotté V, Read A, Birtles RJ, et al. Strategies of exploitation of mammalian reservoirs by Bartonella species. Vet Res. 2012;43:15.

2. Breitschwerdt EB, Maggi RG, Chomel BB, Lappin MR. Bartonellosis: an emerging infectious disease of zoonotic importance to animals and human beings. J Vet Emerg Crit Care. 2010;20:8-30.

3. Chomel BB, Kasten RW, Sykes JE, Boulouis H-J, Breitschwerdt EB. Clinical impact of persistent Bartonella bacteremia in humans and animals. Ann N Y Acad Sci. 2003;990:267-78.

4. Lappin MR, Kordick DL, Breitschwerdt EB. Bartonella spp. antibodies and DNA in aqueous humour of cats. J Feline Med Surg. 2000;2:61-8.

5. Kordick DL, Breitschwerdt EB. Persistent infection of pets within a household with three Bartonella species. Emerg Infect Dis. 1998;4:325-8.

6. Valentine $\mathrm{KH}$, Harms C, Cadenas MB, Birkenheuer AJ, Marr HS, Braun-McNeill J, et al. Bartonella DNA in loggerhead sea turtles. Emerg Infect Dis. 2007;13: 949-50.

7. Chang CC, Chomel BB, Kasten RW, Heller RM, Kocan KM, Ueno H, et al Bartonella spp. isolated from wild and domestic ruminants in North America. Emerg Infect Dis. 2000;6:306-11.

8. Dehio C, Sauder U, Hiestand R. Isolation of Bartonella schoenbuchensis from Lipoptena cervi, a blood-sucking arthropod causing deer ked dermatitis. $J$ Clin Microbiol. 2004;42:5320-3.

9. Jones SL, Maggi R, Shuler J, Alward A, Breitschwerdt EB. Detection of Bartonella henselae in the blood of 2 adult horses. J Vet Intern Med. 2008;22: 495-8.

10. Alsarraf M, Mohallal EME, Mierzejewska EJ, Behnke-Borowczyk J, WelcFalęciak R, Bednarska M, et al. Description of Candidatus Bartonella fadhilae n. sp. and Candidatus Bartonella sanaae n. sp. (Bartonellaceae) from Dipodillus dasyurus and Sekeetamys calurus (Gerbillinae) from the Sinai Massif (Egypt). Vector Borne Zoonotic Dis. 2017;17:483-94.

11. Lamas C, Curi A, Bóia M, Lemos E. Human bartonellosis: seroepidemiological and clinical features with an emphasis on data from Brazil - a review. Mem Inst Oswaldo Cruz. 2008;103:221-35

12. Breitschwerdt EB, Maggi RG, Robert Mozayeni B, Hegarty BC, Bradley JM, Mascarelli PE. PCR amplification of Bartonella koehlerae from human blood and enrichment blood cultures. Parasit Vectors. 2010;3:76

13. Vera CP, Maggi RG, Woods CW, Mascarelli PE, Breitschwerdt EB. Spontaneous onset of complex regional pain syndrome Type I in a woman infected with Bartonella koehlerae. Med Microbiol Immunol. 2014;203:101-7.

14. Breitschwerdt EB, Maggi RG, Varanat M, Linder KE, Weinberg G. Isolation of Bartonella vinsonii subsp. berkhoffii genotype II from a boy with epithelioid hemangioendothelioma and a dog with hemangiopericytoma. J Clin Microbiol. 2009:47:1957-60.

15. Breitschwerdt EB, Maggi RG, Farmer P, Mascarelli PE. Molecular evidence of perinatal transmission of Bartonella vinsonii subsp. berkhoffii and Bartonella henselae to a child. J Clin Microbiol. 2010;48:2289-93.

16. Breitschwerdt EB. Bartonellosis, One Health and all creatures great and small. Vet Dermatol. 2017;28:96-21.

17. Chomel BB, Kasten RW. Bartonellosis, an increasingly recognized zoonosis. J Appl Microbiol. 2010;109:743-50.
18. Jaffe DA, Chomel BB, Kasten RW, Breitschwerdt EB, Maggi RG, McLeish A, et al. Bartonella henselae in small Indian mongooses (Herpestes auropunctatus) from Grenada, West Indies. Vet Microbiol. 2018;216:119-22.

19. Chomel BB, Kasten RW, Floyd-Hawkins K, Chi B, Yamamoto K, RobertsWilson J, et al. Experimental transmission of Bartonella henselae by the cat flea. J Clin Microbiol. 1996:34:1952-6.

20. Chomel BB, Boulouis H-J, Maruyama S, Breitschwerdt EB. Bartonella spp. in pets and effect on human health. Emerg Infect Dis. 2006;12:389-94.

21. Chomel BB, Boulouis HJ, Breitschwerdt EB. Cat scratch disease and other zoonotic Bartonella infections. J Am Vet Med Assoc. 2004;224:1270-9.

22. Avidor B, Graidy M, Efrat G, Leibowitz C, Shapira G, Schattner A, et al. Bartonella koehlerae, a new cat-associated agent of culture-negative human endocarditis. J Clin Microbiol. 2004:42:3462-8.

23. Roux V, Eykyn SJ, Wyllie S, Raoult D. Bartonella vinsonii subsp. berkhoffii as an agent of afebrile blood culture-negative endocarditis in a human. J Clin Microbiol. 2000;38:1698-700.

24. Olarte L, Ampofo K, Thorell EA, Sanderson S, Doby E, Pavia AT, et al. Bartonella vinsonii endocarditis in an adolescent with congenital heart disease. Pediatr Infect Dis. J. 2012:31:531-4.

25. Breitschwerdt EB, Kordick DL. Bartonella infection in animals: carriership, reservoir potential, pathogenicity, and zoonotic potential for human infection. Clin Microbiol Rev. 2000;13:428-38.

26. Chang CC, Kasten RW, Chomel BB, Simpson DC, Hew CM, Kordick DL, et al. Coyotes (Canis latrans) as the reservoir for a human pathogenic Bartonella sp.: molecular epidemiology of Bartonella vinsonii subsp. berkhoffii infection in coyotes from central coastal California. J Clin Microbiol. 2000;38:4193-200.

27. Gundi VAKB, Bourry O, Davoust B, Raoult D, La Scola B. Bartonella clarridgeiae and B. henselae in dogs, Gabon. Emerg Infect Dis. 2004;10:2261-2.

28. Friedenberg SG, Balakrishnan N, Guillaumin J, Cooper ES, Lewis K, Russell DS, et al. Splenic vasculitis, thrombosis, and infarction in a febrile dog infected with Bartonella henselae. J Vet Emerg Crit Care. 2015;25:789-94.

29. Kitchell BE, Fan TM, Kordick D, Breitschwerdt EB, Wollenberg G, Lichtensteiger CA. Peliosis hepatis in a dog infected with Bartonella henselae. J Am Vet Med Assoc. 2000:216:519-23.

30. Tabar M-D, Altet L, Maggi RG, Altimira J, Roura X. First description of Bartonella koehlerae infection in a Spanish dog with infective endocarditis. Parasit Vectors. 2017;10:247.

31. Chomel BB, Wey AC, Kasten RW. Isolation of Bartonella washoensis from a dog with mitral valve endocarditis. J Clin Microbiol. 2003;41:5327-32.

32. Diniz PPVP, Billeter SA, Otranto D, De Caprariis D, Petanides T, Mylonakis ME, et al. Molecular documentation of Bartonella infection in dogs in Greece and Italy. J Clin Microbiol. 2009;47:1565-7.

33. Ihler GM. Bartonella bacilliformis: dangerous pathogen slowly emerging from deep background. FEMS Microbiol Lett. 1996;144:1-11.

34. Keret D, Giladi M, Kletter Y, Wientroub S. Cat-scratch disease osteomyelitis from a dog scratch. J Bone Joint Surg Br. 1998:80:766-7.

35. Vieira-Damiani G, Diniz PPV de P, Pitassi LHU, Sowy S, Scorpio DG, Lania BG, et al. Bartonella clarridgeiae bacteremia detected in an asymptomatic blood donor. J Clin Microbiol. 2015:53:352-6.

36. Breitschwerdt EB, Mascarelli PE, Schweickert LA, Maggi RG, Hegarty BC, Bradley JM, et al. Hallucinations, sensory neuropathy, and peripheral visual deficits in a young woman infected with Bartonella koehlerae. J Clin Microbiol. 2011:49:3415-7.

37. Regier Y, O'Rourke F, Kempf VAJ. Bartonella spp. - a chance to establish One Health concepts in veterinary and human medicine. Parasit Vectors. 2016:9:261.

38. Kelly P, Rolain JM, Maggi R, Sontakke S, Keene B, Hunter S, et al. Bartonella quintana endocarditis in dogs. Emerg Infect Dis. 2006;12:1869-72.

39. Duncan AW, Marr HS, Birkenheuer AJ, Maggi RG, Williams LE, Correa MT, et al. Bartonella DNA in the blood and lymph nodes of golden retrievers with lymphoma and in healthy controls. J Vet Intern Med. 2008;22:89-95.

40. Bai Y, Kosoy MY, Boonmar S, Sawatwong P, Sangmaneedet S, Peruski LF. Enrichment culture and molecular identification of diverse Bartonella species in stray dogs. Vet Microbiol. 2010;146:314-9.

41. Breitschwerdt EB, Maggi RG, Sigmon B, Nicholson WL. Isolation of Bartonella quintana from a woman and a cat following putative bite transmission. J Clin Microbiol. 2007:45:270-2.

42. La VD, Tran-Hung L, Aboudharam G, Raoult D, Drancourt M. Bartonella quintana in domestic cat. Emerg Infect Dis. 2005:11:1287-9.

43. O'Rourke LG, Pitulle C, Hegarty BC, Kraycirik S, Killary KA, Grosenstein P, et al. Bartonella quintana in cynomolgus monkey (Macaca fascicularis). Emerg Infect Dis. 2005;11:1931-4. 
44. Huang R, Liu Q, Li G, Li D, Song X, Birtles RJ, et al. Bartonella quintana infections in captive monkeys, China. Emerg Infect Dis. 2011;17:1707-9.

45. Mosbacher ME, Klotz S, Klotz J, Pinnas JL. Bartonella henselae and the potential for arthropod vector-borne transmission. Vector Borne Zoonotic Dis. 2011;11:471-7.

46. Guptill L. Bartonellosis. Vet Clin North Am Small Anim Pract. 2003;33:809-25.

47. Foil L, Andress E, Freeland RL, Roy AF, Rutledge R, Triche PC, et al. Experimental infection of domestic cats with Bartonella henselae by inoculation of Ctenocephalides felis (Siphonaptera: Pulicidae) feces. J Med Entomol. 1998;35:625-8.

48. Battisti JM, Lawyer PG, Minnick MF. Colonization of Lutzomyia verrucarum and Lutzomyia longipalpis sand flies (Diptera: Psychodidae) by Bartonella bacilliformis, the etiologic agent of Carrión's disease. PLoS Negl Trop Dis. 2015;9:0004128.

49. Cotté V, Bonnet S, Le Rhun D, Le Naour E, Chauvin A, Boulouis HJ, et al. Transmission of Bartonella henselae by Ixodes ricinus. Emerg Infect Dis. 2008; 14:1074-80.

50. Edyta, Chmielewski T, Sochon E, Tylewska-Wierzbanowska S. Bartonella henselae in Ixodes ricinus ticks removed from dogs. Vector Borne Zoonotic Dis. 2007;7:189-92.

51. Müller A, Reiter M, Schötta AM, Stockinger H, Stanek G. Detection of Bartonella spp. in Ixodes ricinus ticks and Bartonella seroprevalence in human populations. Ticks Tick Borne Dis. 2016;7:763-7.

52. Pennisi M-G, Persichetti M-F, Serrano L, Altet L, Reale S, Gulotta L, et al. Ticks and associated pathogens collected from cats in Sicily and Calabria (Italy). Parasit Vectors. 2015;8:512.

53. Lucey D, Dolan MJ, Moss CW, Garcia M, Hollis DG, Wegner S, et al. Relapsing illness due to Rochalimaea henselae in immunocompetent hosts: implication for therapy and new epidemiological associations. Clin Infect Dis. 1992;14:683-8.

54. Breitschwerdt EB, Maggi RG, Nicholson WL, Cherry NA, Woods CW. Bartonella sp. bacteremia in patients with neurological and neurocognitive dysfunction. J Clin Microbiol. 2008:46:2856-61.

55. Maggi RG, Ericson M, Mascarelli PE, Bradley JM, Breitschwerdt EB. Bartonella henselae bacteremia in a mother and son potentially associated with tick exposure. Parasit Vectors. 2013;6:101.

56. Golly E, Breitschwerdt EB, Balakrishnan N, Moore D, Bizikova P. Bartonella henselae, Bartonella koehlerae and Rickettsia rickettsii seroconversion and seroreversion in a dog with acute-onset fever, lameness, and lymphadenopathy followed by a protracted disease course. Vet Parasitol Reg. 2017;7:19-24

57. Bouhsira E, Ferrandez Y, Liu M, Franc M, Boulouis HJ, Biville F. Ctenocephalides felis an in vitro potential vector for five Bartonella species. Comp Immunol Microbiol Infect Dis. 2013;36:105-11.

58. Oliveira AM, Maggi RG, Woods CW, Breitschwerdt EB. Suspected needle stick transmission of Bartonella vinsonii subspecies berkhoffii to a veterinarian. J Vet Intern Med. 2010;24:1229-32.

59. Kordick DL, Breitschwerdt EB. Relapsing bacteremia after blood transmission of Bartonella henselae to cats. Am J Vet Res. 1997;58:492-7.

60. Wardrop KJ, Birkenheuer A, Blais MC, Callan MB, Kohn B, Lappin MR, et al. Update on canine and feline blood donor screening for blood-borne pathogens. J Vet Intern Med. 2016;30:15-35.

61. Núñez MA, Contreras K, Depix MS, Geoffroy E, Villagra N, Mellado S, et al. Prevalencia de Bartonella henselae en donantes de sangre y riesgo de transmisión sanguínea en Chile. Rev Chil Infectología. 2017;34:539-43.

62. Pitassi LHU, de Paiva Diniz PPV, Scorpio DG, Drummond MR, Lania BG, Barjas-Castro ML, et al. Bartonella spp. bacteremia in blood donors from Campinas, Brazil. PLoS Negl Trop Dis. 2015;9:0003467.

63. Bergh K, Bevanger L, Hanssen I, Loseth K. Low prevalence of Bartonella henselae infections in Norwegian domestic and feral cats. Apmis. 2002;110:309-14.

64. Solano-Gallego L, Hegarty B, Espada Y, Llull J, Breitschwerdt E. Serological and molecular evidence of exposure to arthropod-borne organisms in cats from northeastern Spain. Vet Microbiol. 2006;118:274-7.

65. Pennisi MG, Marsilio F, Hartmann K, Lloret A, Addie D, Belák S, et al. Bartonella species infection in cats: $A B C D$ guidelines on prevention and management. J Feline Med Surg. 2013;15:563-9.

66. Rolain J-M, Franc M, Davoust B, Raoult D. Molecular detection of Bartonella quintana, B. koehlerae, B. henselae, B. clarridgeiae, Rickettsia felis, and Wolbachia pipientis in cat fleas, France. Emerg Infect Dis. 2003;9:338-42.

67. Pappalardo BL, Correa MT, York CC, Peat CY, Breitschwerdt EB. Epidemiologic evaluation of the risk factors associated with exposure and seroreactivity to Bartonella vinsonii in dogs. Am J Vet Res. 1997;58:467-71.
68. Solano-Gallego L, Bradley J, Hegarty B, Sigmon B, Breitschwerdt E. Bartonella henselae lgG antibodies are prevalent in dogs from southeastern USA. Vet Res. 2004;35:585-95.

69. Lashnits E, Correa M, Hegarty BC, Birkenheuer A, Breitschwerdt EB. Bartonella seroepidemiology in dogs from North America, 2008-2014. J Vet Intern Med. 2018;32:222-31.

70. Henn JB, Liu C-H, Kasten RW, VanHorn BA, Beckett LA, Kass PH, et al. Seroprevalence of antibodies against Bartonella species and evaluation of risk factors and clinical signs associated with seropositivity in dogs. Am J Vet Res. 2005;66:688-94.

71. Hegarty BC, Bradley JM, Lappin MR, Balakrishnan N, Mascarelli PE, Breitschwerdt EB. Analysis of seroreactivity against cell culture-derived Bartonella spp. antigens in dogs. J Vet Intern Med. 2014;28:38-41.

72. Barnes A, Bell SC, Isherwood DR, Bennett M, Carter SD. Evidence of Bartonella henselae infection in cats and dogs in the United Kingdom. Vet Rec. 2000;147:673-7.

73. Zobba R, Chessa G, Mastrandrea S, Parpaglia MLP, Patta C, Masala G. Serological and molecular detection of Bartonella spp. in humans, cats and dogs from northern Sardinia, Italy. Clin Microbiol Infect. 2009;15:134-5.

74. Solano-Gallego L, Llull J, Osso M, Hegarty B, Breitschwerdt E. A serological study of exposure to arthropod-borne pathogens in dogs from northeastern Spain. Vet Res. 2006;37:231-44.

75. Mellor PJ, Fetz K, Maggi RG, Haugland S, Dunning M, Villiers EJ, et al. Alpha1-proteinase inhibitor deficiency and Bartonella infection in association with panniculitis, polyarthritis, and meningitis in a dog. J Vet Intern Med. 2006;20:1023-8.

76. Michau TM, Breitschwerdt EB, Gilger BC, Davidson MG. Bartonella vinsonii subspecies berkhoffii as a possible cause of anterior uveitis and choroiditis in a dog. Vet Ophthalmol. 2003;6:299-304.

77. Pappalardo BL, Brown T, Gookin JL, Morrill CL, Breitschwerdt EB. Granulomatous disease associated with Bartonella infection in 2 dogs. J Vet Intern Med. 2000;14:37-42.

78. Tuttle AD, Birkenheuer AJ, Juopperi T, Levy MG, Breitschwerdt EB. Concurrent bartonellosis and babesiosis in a dog with persistent thrombocytopenia. J Am Vet Med Assoc. 2003;223:1306-10.

79. Shelnutt LM, Balakrishnan N, DeVanna J, Batey KL, Breitschwerdt EB. Death of military working dogs due to Bartonella vinsonii subspecies berkhoffii genotype III endocarditis and myocarditis. Mil Med. 2017:182:e1864-9.

80. Balakrishnan N, Pritchard J, Ericson M, Grindem C, Phillips K, Jennings $S$, et al. Prostatitis, steatitis, and diarrhea in a dog following presumptive flea-borne transmission of Bartonella henselae. J Clin Microbiol. 2014;52:3447-52.

81. Diniz PPV de P, Wood M, Maggi RG, Sontakke S, Stepnik M, Breitschwerdt EB. Co-isolation of Bartonella henselae and Bartonella vinsonii subsp. berkhoffii from blood, joint and subcutaneous seroma fluids from two naturally infected dogs. Vet Microbiol. 2009;138:368-72

82. Henn JB, Gabriel MW, Kasten RW, Brown RN, Koehler JE, MacDonald KA, et al. Infective endocarditis in a dog and the phylogenetic relationship of the associated "Bartonella rochalimae" strain with isolates from dogs, gray foxes, and a human. J Clin Microbiol. 2009;47:787-90.

83. Cadenas MB, Bradley J, Maggi RG, Takara M, Hegarty BC, Breitschwerdt EB. Molecular characterization of Bartonella vinsonii subsp. berkhoffii genotype III. J Clin Microbiol. 2008;46:1858-60.

84. Saunders GK, Monroe WE. Systemic granulomatous disease and sialometaplasia in a dog with Bartonella infection. Vet Pathol. 2006;43:391-2.

85. Chomel BB, Mac Donald KA, Kasten RW, Chang CC, Wey AC, Foley JE, et al. Aortic valve endocarditis in a dog due to Bartonella clarridgeiae. J Clin Microbiol. 2001:39:3548-54.

86. Breitschwerdt EB, Hegarty BC, Maggi R, Hawkins E, Dyer P. Bartonella species as a potential cause of epistaxis in dogs. J Clin Microbiol. 2005; 43:2529-33.

87. Kordick DL, Swaminathan B, Greene CE, Wilson KH, Whitney AM, O'Connor $\mathrm{S}$, et al. Bartonella vinsonii subsp. berkhoffii subsp. nov., isolated from dogs; Bartonella vinsonii subsp. vinsonii; and emended description of Bartonella vinsonii. Int J Syst Bacteriol. 1996:46:704-9.

88. Breitschwerdt EB, Kordick DL, Malarkey DE, Keene B, Hadfield TL, Wilson K. Endocarditis in a dog due to infection with a novel Bartonella subspecies. J Clin Microbiol. 1995:33:154-60.

89. Yager JA, Best SJ, Maggi RG, Varanat M, Znajda N, Breitschwerdt EB. Bacillary angiomatosis in an immunosuppressed dog. Vet Dermatol. 2010;21:420-8. 
90. Breitschwerdt EB, Maggi RG. A confusing case of canine vector-borne disease: clinical signs and progression in a dog co-infected with Ehrlichia canis and Bartonella vinsonii ssp. berkhoffii. Parasit Vectors. 2009;2(Suppl. 1):S3.

91. Gillespie TN, Washabau RJ, Goldschmidt MH, Cullen JM, Rogala AR, Breitschwerdt EB. Detection of Bartonella henselae and Bartonella clarridgeiae DNA in hepatic specimens from two dogs with hepatic disease. J Am Vet Med Assoc. 2003;222:47-51.

92. Tucker MD, Sellon RK, Tucker RL, Wills TB, Simonsen A, Maggi RG, et al. Bilateral mandibular pyogranulomatous lymphadenitis and pulmonary nodules in a dog with Bartonella henselae bacteremia. Can Vet J La Rev Vet Can. 2014;55:970-4.

93. Cross JR, Rossmeisl JH, Maggi RG, Breitschwerdt EB, Duncan RB. Bartonellaassociated meningoradiculoneuritis and dermatitis or panniculitis in 3 dogs. J Vet Intern Med. 2008;22:674-8.

94. Rossi MA, Balakrishnan N, Linder KE, Messa JB, Breitschwerdt EB. Concurrent Bartonella henselae infection in a dog with panniculitis and owner with ulcerated nodular skin lesions. Vet Dermatol. 2015;26:60-3.

95. Santilli RA, Battaia S, Perego M, Tursi M, Grego E, Marzufero C, et al. Bartonella-associated inflammatory cardiomyopathy in a dog. J Vet Cardiol. 2016;19:74-81.

96. Breitschwerdt EB, Goldkamp C, Castleman WL, Cullen JM, Mascarelli PE, Thalhem $L$, et al. Hyperinsulinemic hypoglycemia syndrome in 2 dogs with bartonellosis. J Vet Intern Med. 2014;28:1331-5.

97. Bradley JM, Mascarelli PE, Trull CL, Maggi RG, Breitschwerdt EB. Bartonella henselae infections in an owner and two papillon dogs exposed to tropical rat mites (Ornithonyssus bacoti). Vector Borne Zoonotic Dis. 2014;14:703-9.

98. Tabar MD, Maggi RG, Altet L, Vilafranca M, Francino O, Roura X. Gammopathy in a Spanish dog infected with Bartonella henselae. J Small Anim Pract. 2011;52:209-12.

99. Morales SC, Breitschwerdt EB, Washabau RJ, Matise I, Maggi RG, Duncan AW. Detection of Bartonella henselae DNA in two dogs with pyogranulomatous lymphadenitis. J Am Vet Med Assoc. 2007;230:681-5.

100. Berkowitz ST, Gannon KM, Carberry CA, Cortes Y. Resolution of spontaneous hemoabdomen secondary to peliosis hepatis following surgery and azithromycin treatment in a Bartonella species infected dog. J Vet Emerg Crit Care 2016:26:851-7.

101. Nelson CA, Saha S, Mead PS. Cat-scratch disease in the United States, 20052013. Emerg Infect Dis. 2016;22:1741-6.

102. Tea A, Alexiou-Daniel S, Arvanitidou M, Diza E, Antoniadis A. Occurrence of Bartonella henselae and Bartonella quintana in a healthy Greek population. Am J Trop Med Hyg. 2003;68:554-6.

103. Blanco Ramos JR, Oteo Revuelta JA, Martinez de Artola V, Ramalle Gomara E, Garcia Pineda A, Ibarra Cucalon V, et al. Seroepidemiology of Bartonella henselae infection in a risk group. Rev Clin Esp. 1998;198:805-9.

104. Oteo JA, Maggi R, Portillo A, Bradley J, García-Álvarez L, San-Martín M, et al. Prevalence of Bartonella spp. by culture, PCR and serology, in veterinary personnel from Spain. Parasit Vectors. 2017;10:553.

105. Schülein R, Seubert A, Gille C, Lanz C, Hansmann Y, Piémont Y, et al. Invasion and persistent intracellular colonization of erythrocytes. A unique parasitic strategy of the emerging pathogen Bartonella. J Exp Med. 2001; 193:1077-86.

106. da Silva MN, Vieira-Damiani G, Ericson ME, Gupta K, de Almeida AR, Drummond MR, et al. Acute and late Bartonella henselae murine model infection. Vector Borne Zoonotic Dis. 2017;17:206-8.

107. Silva MN, Vieira-Damiani G, Ericson ME, Gupta K, Gilioli R, de Almeida AR, et al. Bartonella henselae transmission by blood transfusion in mice. Transfusion. 2016:56:1556-9.

108. Karem KL, Dubois KA, McGill SL, Regnery RL. Characterization of Bartonella henselae-specific immunity in BALB/C mice. Immunology. 1999;97:352-8.

109. Dehio C. Bartonella interactions with endothelial cells and erythrocytes. Trends Microbiol. 2001;9:279-85.

110. Hong J, Li Y, Hua X, Bai Y, Wang C, Zhu C, et al. Inhibition of phagocytosis and pyroptosis of macrophages promotes Bartonella invasion into the bloodstream through lymphatic circulation. J Infect Dis. 2016;4:526.

111. Balakrishnan N, Cherry NA, Linder KE, Pierce E, Sontakke N, Hegarty $B C$, et al. Experimental infection of dogs with Bartonella henselae and Bartonella vinsonii subsp. berkhoffii. Vet Immunol Immunopathol. 2013;156:153-8.

112. Kordick DL, Brown TT, Shin K, Breitschwerdt EB. Clinical and pathologic evaluation of chronic Bartonella henselae or Bartonella clarridgeiae infection in cats. J Clin Microbiol. 1999;37:1536-47.
113. Mändle T, Einsele $H$, Schaller $M$, Neumann D, Vogel W, Autenrieth IB, et al. Infection of human CD34+ progenitor cells with Bartonella henselae results in intraerythrocytic presence of B. henselae. Blood. 2005;106:1215-22.

114. Kempf VA, Volkmann B, Schaller M, Sander CA, Alitalo K, Riess T, et al. Evidence of a leading role for VEGF in Bartonella henselae-induced endothelial cell proliferations. Cell Microbiol. 2001;3:623-32.

115. Maeno N, Oda H, Yoshiie K, Wahid MR, Fujimura T, Matayoshi S. Live Bartonella henselae enhances endothelial cell proliferation without direct contact. Microb Pathog. 1999;27:419-27.

116. Muñana KR, Vitek SM, Hegarty BC, Kordick DL, Breitschwerdt EB. Infection of fetal feline brain cells in culture with Bartonella henselae. Infect Immun. 2001;69:564-9.

117. Dehio C. Molecular and cellular basis of Bartonella pathogenesis. Annu Rev Microbiol. 2004;58:365-90.

118. Dehio C. Bartonella-host-cell interactions and vascular tumour formation. Nat Rev Microbiol. 2005;3:621-31.

119. Abbott RC, Chomel BB, Kasten RW, Floyd-Hawkins KA, Kikuchi Y, Koehler JE, et al. Experimental and natural infection with Bartonella henselae in domestic cats. Comp Immunol Microbiol Infect Dis. 1997;20:41-51.

120. Pulliainen AT, Dehio C. Persistence of Bartonella spp. stealth pathogens: from subclinical infections to vasoproliferative tumor formation. FEMS Microbiol Rev. 2012;36:563-99.

121. Beerlage C, Varanat M, Linder K, Maggi RG, Cooley J, Kempf VAJ, et al. Bartonella vinsonii subsp. berkhoffii and Bartonella henselae as potentia causes of proliferative vascular diseases in animals. Med Microbiol Immunol. 2012;201:319-26.

122. Fuji RN, Patton KM, Steinbach TJ, Schulman FY, Bradley GA, Brown TT, et al. Feline systemic reactive angioendotheliomatosis: eight cases and literature review. Vet Pathol. 2005;42:608-17.

123. Maguiña C, Guerra H, Ventosilla P. Bartonellosis. Clin Dermatol. 2009;27:271-80.

124. Mazur-Melewska K, Mania A, Kemnitz P, Figlerowicz M, Służewski W. Catscratch disease: a wide spectrum of clinical pictures. Postepy Dermatol Alergol. 2015;32:216-20.

125. Stützer B, Hartmann K. Chronic Bartonellosis in Cats. J Feline Med Surg. 2012;14:612-21.

126. Buchmann AU, Kershaw O, Kempf VAJ, Gruber AD. Does a feline leukemia virus infection pave the way for Bartonella henselae infection in cats? I Clin Microbiol. 2010;48:3295-300.

127. Aylló T, Paulo P, Diniz VP, Breitschwerdt EB, Villaescusa A, Rodríguez-Franco F, et al. Vector-borne diseases in client-owned and stray cats from Madrid, Spain. Vector Borne Zoonotic Dis. 2012;12:143-50.

128. Pérez C, Maggi RG, Diniz PPVP, Breitschwerdt EB. Molecular and serological diagnosis of Bartonella infection in 61 dogs from the United States. J Vet Intern Med. 2011;25:805-10.

129. Varanat M, Maggi RG, Linder KE, Breitschwerdt EB. Molecular prevalence of Bartonella, Babesia, and hemotropic Mycoplasma sp. in dogs with splenic disease. J Vet Intern Med. 2011;25:1284-91.

130. Ahsan N, Holman MJ, Riley TR, Abendroth CS, Langhoff EG, Yang HC. Peliosis hepatis due to Bartonella henselae in transplantation: a hematohepato-renal syndrome. Transplantation. 1998;65:1000-3.

131. Koehler JE, Sanchez MA, Garrido CS, Whitfeld MJ, Chen FM, Berger TG, et al. Molecular epidemiology of Bartonella infections in patients with bacillary angiomatosis-peliosis. N Engl J Med. 1997;337:1876-83.

132. Pérez Vera C, Paulo P, Diniz VP, Pultorak EL, Maggi RG, Breitschwerdt EB. An unmatched case controlled study of clinicopathologic abnormalities in dogs with Bartonella infection. Comp Immunol Microbiol Infect Dis. 2013;36:481-7.

133. Breitschwerdt EB. Bartonellosis: One Health perspectives for an emerging infectious disease. ILAR J. 2014;55:46-58.

134. Drut A, Bublot I, Breitschwerdt EB, Chabanne L, Vayssier-Taussat M, Cadoré $J$-L. Comparative microbiological features of Bartonella henselae infection in a dog with fever of unknown origin and granulomatous lymphadenitis. Med Microbiol Immunol. 2014;203:85-91.

135. Lösch B, Wank R. Life-threatening angioedema of the tongue: the detection of the RNA of B henselae in the saliva of a male patient and his dog as well as of the DNA of three Bartonella species in the blood of the patient. BMJ Case Rep. 2014;bcr2013203107.

136. Roura X, Santamarina G, Tabar M-D, Francino O, Altet L. Polymerase chain reaction detection of Bartonella spp. in dogs from Spain with blood culturenegative infectious endocarditis. J Vet Cardiol. 2018;20:267-75.

137. Clarridge JE, Raich TJ, Pirwani D, Simon B, Tsai L, Rodriguez-Barradas MC, et al. Strategy to detect and identify Bartonella species in routine clinical 
laboratory yields Bartonella henselae from human immunodeficiency viruspositive patient and unique Bartonella strain from his cat. J Clin Microbiol. 1995:33:2107-13.

138. Weeden AL, Cherry NA, Breitschwerdt EB, Cheves AG, Wamsley HL. Bartonella henselae in canine cavitary effusions: prevalence, identification, and clinical associations. Vet Clin Pathol. 2017;46:326-30.

139. Lee SA, Plett SK, Luetkemeyer AF, Borgo GM, Ohliger MA, Conrad MB, et al. Bartonella quintana aortitis in a man with AIDS, diagnosed by needle biopsy and 16S rRNA gene amplification. J Clin Microbiol. 2015;53:2773-6.

140. Breitschwerdt EB. Feline bartonellosis and cat scratch disease. Vet Immunol Immunopathol. 2008;123:167-71.

141. Burzo ML, Antonelli M, Pecorini G, Favuzzi AMR, Landolfi R, Flex A. Fever of unknown origin and splenomegaly: a case report of blood culture negative endocarditis. Medicine. 2017;96:e9197.

142. Pultorak EL, Maggi RG, Mascarelli PE, Breitschwerdt EB. Serial testing from a 3-day collection period by use of the Bartonella Alphaproteobacteria growth medium platform may enhance the sensitivity of Bartonella species detection in bacteremic human patients. J Clin Microbiol. 2013;51:1673-7.

143. Duncan AW, Maggi RG, Breitschwerdt EB. A combined approach for the enhanced detection and isolation of Bartonella species in dog blood samples: pre-enrichment liquid culture followed by PCR and subculture onto agar plates. J Microbiol Methods. 2007;69:273-81.

144. Davenport AC, Mascarelli PE, Maggi RG, Breitschwerdt EB. Phylogenetic diversity of bacteria isolated from sick dogs using the BAPGM enrichment culture platform. J Vet Intern Med. 2013;27:854-61.

145. Dumler JS, Scorpio DG. Bartonella. In: Manual of clinical microbiology. 11th ed. Washington: ASM Press; 2015. p. 873-86.

146. Diddi K, Chaudhry R, Sharma N, Dhawan B. Strategy for identification \& characterization of Bartonella henselae with conventional molecular methods. Indian J Med Res. 2013;137:380-7.

147. Namekata DY, Kasten RW, Boman DA, Straub MH, Siperstein-Cook L, Couvelaire $\mathrm{K}$, et al. Oral shedding of Bartonella in cats: correlation with bacteremia and seropositivity. Vet Microbiol. 2010;46:371-5.

148. Pennisi MG, La Camera E, Giacobbe L, Orlandella BM, Lentini V, Zummo S, et al. Molecular detection of Bartonella henselae and Bartonella clarridgeiae in clinical samples of pet cats from southern Italy. Res Vet Sci. 2010;88:379-84.

149. Duncan AW, Maggi RG, Breitschwerdt EB. Bartonella DNA in dog saliva. Emerg Infect Dis. 2007;13:1948-50.

150. Glaus T, Hofmann-Lehmann R, Greene C, Glaus B, Wolfensberger C, Lutz AH. Seroprevalence of Bartonella henselae infection and correlation with disease status in cats in Switzerland. J Clin Microbiol. 1997;35:2883-5.

151. Chomel BB, Abbott RC, Kasten RW, Floyd-Hawkins KA, Kass PH, Glaser CA, et al. Bartonella henselae prevalence in domestic cats in California: risk factors and association between bacteremia and antibody titers. J Clin Microbiol. 1995:33:2445-50.

152. Reller LB, Weinstein MP, Procop GW, Wilson M. Infectious disease pathology. Clin Infect Dis. 2001;32:1589-601.

153. Varanat M, Broadhurst J, Linder KE, Maggi RG, Breitschwerdt EB. Identification of Bartonella henselae in 2 cats with pyogranulomatous myocarditis and diaphragmatic myositis. Vet Pathol. 2012;49:608-11.

154. Varanat M, Broadhurst J, Linder KE, Maggi RG, Breitschwerdt EB. Clinical and diagnostic aspects of feline cutaneous leishmaniosis in Venezuela. Vet Pathol. 2012:49:608-11.

155. Pachirat O, Kosoy M, Bai Y, Prathani S, Puapairoj A, Zeidner N, et al. The first reported case of Bartonella endocarditis in Thailand. Infect Dis Rep. 2011;3:e9.

156. Caponetti GC, Pantanowitz L, Marconi S, Havens JM, Lamps LW, Otis CN. Evaluation of immunohistochemistry in identifying Bartonella henselae in cat-scratch disease. Am. J. Clin. Pathol. 2009;131:250-6.

157. Buchmann AU, Kempf VAJ, Kershaw O, Gruber AD. Peliosis hepatis in cats is not associated with Bartonella henselae infections. Vet Pathol. 2010;47:163-6.

158. Webster JD, Miller MA, DuSold D, Ramos-Vara J. Effects of prolonged formalin fixation on the immunohistochemical detection of infectious agents in formalin-fixed, paraffin-embedded tissues. Vet Pathol. 2010;47: 529-35

159. Rolain JM, La SB, Liang Z, Davoust B, Raoult AD. Immunofluorescent detection of intraerythrocytic Bartonella henselae in naturally infected cats. J Clin Microbiol. 2001;39:2978-80.

160. Randell MG, Balakrishnan N, Gunn-Christie R, Mackin A, Breitschwerdt EB. Bartonella henselae infection in a dog with recalcitrant ineffective erythropoiesis. Vet Clin Pathol. 2018;47:45-50.
161. Balakrishnan N, Musulin S, Varanat M, Bradley JM, Breitschwerdt EB. Serological and molecular prevalence of selected canine vector borne pathogens in blood donor candidates, clinically healthy volunteers, and stray dogs in North Carolina. Parasit Vectors. 2014;7:116.

162. Breitschwerdt EB, Maggi RG, Lantos PM, Woods CW, Hegarty BC, Bradley JM. Bartonella vinsonii subsp. berkhoffii and Bartonella henselae bacteremia in a father and daughter with neurological disease. Parasit Vectors. 2010;3:29.

163. Stull JW, Stevenson KB. Zoonotic disease risks for immunocompromised and other high-risk clients and staff: promoting safe pet ownership and contact. Vet Clin North Am Small Anim Pract. 2015;45:377-92.

164. Brunt J, Guptill L, Kordick DL, Kudrak S, Lappin MR. American Association of Feline Practitioners 2006 Panel report on diagnosis, treatment, and prevention of Bartonella spp. infections. J Feline Med Surg. 2006;8:213-26.

165. Guptill L. Feline bartonellosis. Vet Clin North Am Small Anim Pract. 2010;40: 1073-90.

166. Greene CE, McDermott M, Jameson PH, Atkins CL, Marks AM. Bartonella henselae infection in cats: evaluation during primary infection, treatment, and rechallenge infection. J Clin Microbiol. 1996;34:1682-5.

167. Breitschwerdt EB. Treatment of canine and feline bartonellosis. https:// cvm.ncsu.edu/documents/vector-borne-treatment_bartonellosis/. Accessed May 2014.

168. Varanat M, Travis A, Lee W, Maggi RG, Bissett SA, Linder KE, et al. Recurrent osteomyelitis in a cat due to infection with Bartonella vinsonii subsp. berkhoffii genotype II. J Vet Intern Med. 2009;23:1273-7.

169. Breitschwerdt EB, Chomel BB. Canine bartonellosis. In: Greene CE, editor. Infectious Diseases of the Dog and Cat. 4th ed. St. Louis: Elsevier; 2011. p. 552-62.

170. Lappin MR, Black JC. Bartonella spp infection as a possible cause of uveitis in a cat. J Am Vet Med Assoc. 1999;214:1205-7.

171. Lappin MR, Davis WL, Hawley JR, Brewer M, Morris A, Stanneck D. A flea and tick collar containing 10\% imidacloprid and $4.5 \%$ flumethrin prevents flea transmission of Bartonella henselae in cats. Parasit Vectors. 2013;6:26.

172. Urushadze L, Bai Y, Osikowicz L, McKee C, Sidamonidze K, Putkaradze D, et al. Prevalence, diversity, and host associations of Bartonella strains in bats from Georgia (Caucasus). Trop. Dis. 2017;12:e0005428.

173. Stuckey MJ, Boulouis H-J, Cliquet F, Picard-Meyer E, Servat A, AréchigaCeballos N, et al. Potentially zoonotic Bartonella in bats from France and Spain. Emerg. Infect. Dis. 2017;23:539-41.

174. Rozental T, Ferreira MS, Guterres A, Mares-Guia MA, Teixeira BR, Gonçalves J, et al. Zoonotic pathogens in Atlantic Forest wild rodents in Brazil: Bartonella and Coxiella infections. Acta Trop. 2017;168.

175. Telford SR, Wormseer GP. Bartonella spp. transmission by ticks not established. Emerg Infect Dis. 2010;16:379-84.

176. Billeter SA, Levy MG, Chomel BB, Breitschwerdt EB. Vector transmission of Bartonella species with emphasis on the potential for tick transmission. Med Vet Entomol. 2008;22:1-15.

177. Melter O, Arvand M, Votýpka J, Hulínská D. Bartonella quintana transmission from mite to family with high socioeconomic status. Emerg Infect Dis. 2012; 18:163-5.

178. Mylonakis ME, Schreeg M, Chatzis MK, Pearce J, Marr HS, Saridomichelakis MN, et al. Molecular detection of vector-borne pathogens in Greek cats. Ticks Tick Borne Dis. 2018;9:171-5.

179. Lantos PM, Maggi RG, Ferguson B, Varkey J, Park LP, Breitschwerdt EB, et al. Detection of Bartonella species in the blood of veterinarians and veterinary technicians: a newly recognized occupational hazard? Vector Borne Zoonotic Dis. 2014:14:563-70.

180. Cherry NA, Jones SL, Maggi RG, Davis JL, Breitschwerdt EB. Bartonella spp. infection in healthy and sick horses and foals from the southeastern United States. J Vet Intern Med. 2012;26:1408-12.

181. Oksi J, Rantala S, Kilpinen S, Silvennoinen R, Vornanen M, Veikkolainen V, et al. Cat scratch disease caused by Bartonella grahamii in an immunocompromised patient. J Clin Microbiol. 2013;51:2781-4.

182. Silaghi C, Knaus M, Rapti D, Kusi I, Shukullari E, Hamel D, et al. Survey of Toxoplasma gondii and Neospora caninum, haemotropic mycoplasmas and other arthropod-borne pathogens in cats from Albania. Parasit Vectors. 2014;7:62

183. Attipa C, Papasouliotis K, Solano-Gallego L, Baneth G, Nachum-Biala Y, Sarvani $E$, et al. Prevalence study and risk factor analysis of selected bacterial, protozoal and viral, including vector-borne, pathogens in cats from Cyprus. Parasit Vectors. 2017;10:130.

184. Diakou A, Di Cesare A, Accettura PM, Barros L, lorio R, Paoletti B, et al. Intestinal parasites and vector-borne pathogens in stray and free-roaming 
cats living in continental and insular Greece. PLoS Negl Trop Dis. 2017;11: e0005335.

185. Melter O. Detection and characterization of feline Bartonella henselae in the Czech Republic. Vet Microbiol. 2003;93:261-73.

186. Chomel BB, Boulouis H-J, Petersen H, Kasten RW, Yamamoto K, Chang C-C, et al. Prevalence of Bartonella infection in domestic cats in Denmark. Vet Res. 2002;33:205-13.

187. Heller R, Artois M, Xemar V, De Briel D, Gehin H, Jaulhac B, et al. Prevalence of Bartonella henselae and Bartonella clarridgeiae in stray cats. I Clin Microbiol. 1997;35:1327-31.

188. Gurfield AN, Boulouis H-J, Chomel BB, Kasten RW, Heller R, Bouillin C, et al. Epidemiology of Bartonella infection in domestic cats in France. Vet Microbiol. 2001;80:185-98.

189. Rolain J-M, Locatelli C, Chabanne L, Davoust B, Raoult D. Prevalence of Bartonella clarridgeiae and Bartonella henselae in domestic cats from France and detection of the organisms in erythrocytes by immunofluorescence. Clin Diagn Lab Immunol. 2004;11:423-5.

190. Sander A, Hler CB, Pelz K, Von Cramm E, Bredt W. Detection and identification of two Bartonella henselae variants in domestic cats in Germany. J Clin Microbiol. 1997;35:584-7.

191. Haimerl M, Tenter AM, Simon K, Rommel M, Hilger J, Autenrieth IB. Seroprevalence of Bartonella henselae in cats in Germany. J Med Microbiol. 1999:48:849-56.

192. Arvand M, Klose AJ, Schwartz-Porsche D, Hahn H, Wendt C. Genetic variability and prevalence of Bartonella henselae in cats in Berlin, Germany, and analysis of its genetic relatedness to a strain from Berlin that is pathogenic for humans. J Clin Microbiol. 2001;39:743-6.

193. Mietze A, Morick D, Köhler H, Harrus S, Dehio C, Nolte I, et al. Combined MLST and AFLP typing of Bartonella henselae isolated from cats reveals new sequence types and suggests clonal evolution. Vet Microbiol. 2011;148:238-45.

194. Morgenthal D, Hamel D, Arndt G, Silaghi C, Pfister K, Kempf VAJ, et al. Prevalence of haemotropic Mycoplasma spp., Bartonella spp. and Anaplasma phagocytophilum in cats in Berlin/Brandenburg (Northeast Germany). Berl Munch Tierarztl Wochenschr. 2012;125:418-27.

195. Bergmann M, Englert T, Stuetzer B, Hawley JR, Lappin MR, Hartmann K. Prevalence of Bartonella species infections in cats in southern Germany. Vet Rec. 2017;180:325.

196. Ebani W, Cerri D, Andreani E. Cat scratch disease. Survey on the presence of Bartonella henselae among cats of Tuscany. New Microbiol. 2002;25:307-13.

197. Cabassi CS, Farnetti E, Casali B, Taddei S, Donofrio G, Galvani G, et al. Isolation of Bartonella henselae from domestic cats in an Italian urban area. New Microbiol. 2002;25:253-7.

198. Fabbi M, Vicari N, Tranquillo M, Pozzi C, Prati P, De Meneghi D, et al. Prevalence of Bartonella henselae in stray and domestic cats in different Italian areas: evaluation of the potential risk of transmission of Bartonella to humans. Parassitologia. 2004:46:127-9.

199. Pinna Parpaglia ML, Masu G, Masala G, Porcu R, Zobba R, Pintori G, et al. Seroprevalence of Bartonella henselae in dogs and cats in Sassari. Vet Res Commun. 2007;31:317-20.

200. Mansueto P, Pepe I, Cillari E, Arcoleo F, Micalizzi A, Bonura F, et al. Prevalence of antibodies anti- Bartonella henselae in western sicily: children, blood donors, and cats. J Immunoass Immunochem. 2012;33:18-25.

201. Ebani W, Bertelloni F, Fratini F. Occurrence of Bartonella henselae types I and II in central Italian domestic cats. Res Vet Sci. 2012;93:63-6.

202. Brunetti E, Fabbi M, Ferraioli G, Prati P, Filice C, Sassera D, et al. Cat-scratch disease in northern Italy: atypical clinical manifestations in humans and prevalence of Bartonella infection in cats. Eur J Clin Microbiol Infect Dis. 2013:32:531-4

203. Spada E, Canzi I, Baggiani L, Perego R, Vitale F, Migliazzo A, et al. Prevalence of Leishmania infantum and co-infections in stray cats in northern Italy. Comp Immunol. Microbiol Infect Dis. 2016:45:53-8.

204. Persichetti M-F, Solano-Gallego L, Serrano L, Altet L, Reale S, Masucci M, et al. Detection of vector-borne pathogens in cats and their ectoparasites in southern Italy. Parasit Vectors. 2016;9:247.

205. Otranto D, Napoli E, Latrofa MS, Annoscia G, Tarallo VD, Greco G, et al. Feline and canine leishmaniosis and other vector-borne diseases in the Aeolian Islands: pathogen and vector circulation in a confined environment Vet Parasitol. 2017;236:144-51.

206. Juvet F, Lappin MR, Brennan S, Mooney CT. Prevalence of selected infectious agents in cats in Ireland. J Feline Med Surg. 2010;12:476-82.
207. Bergmans AMC, De Jong CMA, Van Amerongen G, Schot CS, Schouls ALM Prevalence of Bartonella species in domestic cats in the Netherlands. J Clin Microbiol. 1997;35:2256-61.

208. Podsiadly E, Chmielewski T, Marczak R, Sochon E, Tylewska-Wierzbanowska S. Bartonella henselae in the human environment in Poland. Scand I Infect Dis. 2007:39:956-62.

209. Alves AS, Milhano N, Santos-Silva M, Santos AS, Vilhena M, de Sousa R. Evidence of Bartonella spp., Rickettsia spp. and Anaplasma phagocytophilum in domestic, shelter and stray cat blood and fleas, Portugal. Clin Microbiol Infect. 2009;15(Suppl. 2):1-3.

210. Childs JE, Olson JG, Wolf A, Cohen N, Fakile Y, Rooney JA, et al. Prevalence of antibodies to Rochalimaea species (cat-scratch disease agent) in cats. Vet Rec. 1995;136:519-20.

211. Maia C, Ramos C, Coimbra M, Bastos F, Martins A, Pinto P, et al. Bacterial and protozoal agents of feline vector-borne diseases in domestic and stray cats from southern Portugal. Parasit Vectors. 2014;7:115.

212. Pons I, Sanfeliu I, Quesada M, Anton E, Sampere M, Font B, et al. Prevalence of Bartonella henselae in cats in Catalonia, Spain. Am J Trop Med Hyg. 2005; 72:453-7.

213. Tabar MD, Altet L, Francino O, Sánchez A, Ferrer L, Roura X. Vector-borne infections in cats: molecular study in Barcelona area (Spain). Vet Parasitol. 2008;151:332-6.

214. Gil H, Escudero R, Pons I, Rodríguez-Vargas M, García-Esteban C, RodríguezMoreno I, et al. Distribution of Bartonella henselae variants in patients, reservoir hosts and vectors in Spain. PLoS One. 2013;8:e68248.

215. Gracia MJ, Marcén JM, Pinal R, Calvete C, Rodes D. Prevalence of Rickettsia and Bartonella species in Spanish cats and their fleas. J Vector Ecol. 2015;40: 233-9.

216. Alamán Valtierra M, Simón Valencia C, Fuertes Negro H, Unzueta Galarza A, Flores Somarriba B, Halaihel KN. Molecular epidemiology of Bartonella henselae in stray and sheltered cats of Zaragoza, Spain. Rev Esp Salud Publica. 2016;90:E5.

217. Ravicini S, Pastor J, Hawley J, Brewer M, Castro-López J, Beall M, et al. Prevalence of selected infectious disease agents in stray cats in Catalonia, Spain. JFMS Open Rep. 2016;2:2055116916634109.

218. Bennett AD, Gunn-Moore DA, Brewer M, Lappin MR. Prevalence of Bartonella species, haemoplasmas and Toxoplasma gondii in cats in Scotland. J Fel Med Surg. 2011;13:553-7.

219. Hjelm E, McGill S, Blomqvist G. Prevalence of antibodies to Bartonella henselae, B. elizabethae and B. quintana in Swedish domestic cats. Scand J Infect Dis. 2002;34:192-6.

220. Olsson Engvall E, Fasth C, Brandstrom B, Fermer C, Blomqvist G, Englund L. Prevalence of Bartonella henselae in young, healthy cats in Sweden. Vet Rec. 2003;152:366-9.

221. Birtles RJ, Laycock G, Day MJ, Kenny MJ, Shaw SE. Prevalence of Bartonella species causing bacteraemia in domesticated and companion animals in the United Kingdom. Vet Rec. 2002;151:225-9.

222. Hamel D, Silaghi C, Knaus M, Visser M, Kusi I, Rapti D, et al. Detection of Babesia canis subspecies and other arthropod-borne diseases in dogs from Tirana, Albania. Wien Klin. 2009;121:42.

223. Pérez Vera C, Kapiainen S, Junnikkala S, Aaltonen K, Spillmann T, Vapalahti O. Survey of selected tick-borne diseases in dogs in Finland. Parasit Vectors. 2014;7:285.

224. Di Francesco A, Sanguinetti V, Gallina L, Gavioli R, Piva S, Baldelli R. Prevalence of antibodies to Bartonella henselae in dogs in Italy. Vet Rec. 2007;161:489-90.

225. Rymaszewska A, Adamska M. Molecular evidence of vector-borne pathogens coinfecting dogs from Poland. Acta Vet Hung. 2011;59:215-23.

226. Tabar M-D, Francino O, Altet L, Sanchez A, Ferrer L, Roura X. PCR survey of vectorborne pathogens in dogs living in and around Barcelona, an area endemic for leishmaniosis. Vet Rec. 2009;164:112-6.

227. Baxarias M, Álvarez-Fernández A, Martínez-Orellana P, Montserrat-Sangrà S, Ordeix L, Rojas A, et al. Does co-infection with vector-borne pathogens play a role in clinical canine leishmaniosis? Parasit Vectors. 2018;11:135.

228. Tabar M-D, Movilla R, Serrano L, Altet L, Francino O, Roura X. PCR evaluation of selected vector-borne pathogens in dogs with pericardial effusion. J Small Anim Pract. 2018;59:248-52.

229. Tiao N, Darrington C, Molla B, Saville WJA, Tilahun GKOC. An investigation into the seroprevalence of Toxoplasma gondii, Bartonella spp., feline immunodeficiency virus (FIV), and feline leukaemia virus (FeLV) in cats in Addis Ababa, Ethiopia. Epidemiol Infect. 2013;141:1029-33. 
230. Bessas A, Leulmi H, Bitam I, Zaidi S, Ait-Oudhia K, Raoult D, et al. Molecular evidence of vector-borne pathogens in dogs and cats and their ectoparasites in Algiers, Algeria. Comp Immunol Microbiol Infect Dis. 2016;45:23-8.

231. Azzag N, Haddad N, Durand B, Petit E, Ammouche A, Chomel B, et al. Population structure of Bartonella henselae in Algerian urban stray cats. PLoS One. 2012;7:43621.

232. Al-Kappany YM, Lappin MR, Kwok OCH, Abu-Elwafa SA, Hilali M, Dubey JP. Seroprevalence of Toxoplasma gondii and concurrent Bartonella spp., feline immunodeficiency virus, feline leukemia virus, and Dirofilaria immitis infections in Egyptian cats. J Parasitol. 2011;97:256-8.

233. Trataris AN, Rossouw J, Arntzen L, Karstaedt A, Frean J. Bartonella spp. in human and animal populations in Gauteng, South Africa, from 2007 to 2009. Onderstepoort J Vet Res. 2012;79:452.

234. Lobetti R, Lappin MR. Prevalence of Toxoplasma gondii, Bartonella species and haemoplasma infection in cats in South Africa. J Feline Med Surg. 2012; 14:857-62.

235. Kelly PJ, Rooney JJ, Marston EL, Jones DC, Regnery RL. Bartonella henselae isolated from cats in Zimbabwe. Lancet. 1998;351:1706.

236. Kelly PJ, Matthewman LA, Hayter D, Downey S, Wray K, Bryson NR, et al. Bartonella (Rochalimaea) henselae in southern Africa evidence for infections in domestic cats and implications for veterinarians. J S Afr Vet Assoc. 1996; 67:182-7.

237. Yuan C, Zhu C, Wu Y, Pan X, Hua X. Bacteriological and molecular identification of Bartonella species in cats from different regions of China. PLoS Negl Trop Dis. 2011;5:e1301.

238. Maruyama S, Nakamura Y, Kabeya H, Tanaka S, Sakai TKY. Prevalence of Bartonella henselae, Bartonella clarridgeiae and the 16S rRNA gene types of Bartonella henselae among pet cats in Japan. J Vet Med Sci. 2000;62:273-9.

239. Sato S, Kabeya H, Negishi A, Tsujimoto H, Nishigaki KEY. Molecular survey of Bartonella henselae and Bartonella clarridgeiae in pet cats across Japan by species-specific nested-PCR. Epidemiol Infect. 2017;145:2694-700.

240. Maruyama S, Kabeya H, Nakao R, Tanaka S, Sakai T, Xuan X, et al. Seroprevalence of Bartonella henselae, Toxoplasma gondii, FIV and FeLV infections in domestic cats in Japan. Microbiol Immunol. 2003:47:147-53.

241. Kim Y, Seo K, Lee J, Choi E, Lee H, Hwang C, et al. Prevalence of Bartonella henselae and Bartonella clarridgeiae in cats and dogs in Korea. J Vet Sci. 2009;10:85-7.

242. Switzer AD, McMillan-Cole AC, Kasten RW, Stuckey MJ, Kass PH, Chomel BB. Bartonella and Toxoplasma infections in stray cats from Iraq. Am J Trop Med Hyg. 2013;89:1219-24.

243. Baneth G, Kordick DL, Hegarty BC, Breitschwerdt EB. Comparative seroreactivity to Bartonella henselae and Bartonella quintana among cats from Israel and North Carolina. Vet Microbiol. 1996:50:95-103.

244. Guzel M, Celebi B, Yalcin E, Koenhemsi L, Mamak N, Pasa S, et al. A serological investigation of Bartonella henselae infection in cats in Turkey. J Vet Med Sci. 2011;73:1513-6.

245. Celebi B, Kilic S, Aydin N, Tarhan G, Carhan A, Babur C. Investigation of Bartonella henselae in cats in Ankara, Turkey. Zoonoses Public Health. 2009; 56:169-75.

246. Gutiérrez R, Morick D, Gross I, Winkler R, Abdeen Z, Harrus S. Bartonella in domestic and stray cats from Israel: comparison of bacterial cultures and high-resolution melt real-time PCR as diagnostic methods. Vector Borne Zoonotic Dis. 2013;13:857-64.

247. Chomel BB, Carlos ET, Kasten RW, Yamamoto K, Chang C-C, Carlos RS, et al. Bartonella henselae and Bartonella clarridgeiae infection in domestic cats from the philippines. Am J Trop Med Hyg. 1999;60:593-7.

248. Maruyama S, Sakai T, Morita Y, Tanaka S, Kabeya H, Boonmar S, et al. Prevalence of Bartonella species and 16S rRNA gene types of Bartonella henselae from domestic cats in Thailand. Am J Trop Med Hyg. 2001;65:783-7.

249. Barrs V, Beatty J, Wilson B, Evans N, Gowan R, Baral R, et al. Prevalence of Bartonella species, Rickettsia felis, haemoplasmas and the Ehrlichia group in the blood of cats and fleas in eastern Australia. Aust Vet J. 2010;88:160-5.

250. Branley J, Wolfson C, Waters P, Gottlieb T, Bradbury R. Prevalence of Bartonella henselae bacteremia, the causative agent of cat scratch disease, in an Australian cat population. Pathology. 1996;28:262-5.

251. Dybing NA, Jacobson C, Irwin P, Algar D, Adams PJ. Bartonella species identified in rodent and feline hosts from island and mainland western Australia. Vector Borne Zoonotic Dis. 2016;16:238-44.

252. Jameson P, Greene C, Regnery R, Dryden M, Marks A, Brown J, et al. Prevalence of Bartonella henselae antibodies in pet cats throughout regions of North America. J Infect Dis. 1995;172:1145-9.
253. Dubey JP, Bhatia CR, Lappin MR, Ferreira LR, Thorn A, Kwok OCH. Seroprevalence of Toxoplasma gondii and Bartonella spp. antibodies in cats from Pennsylvania. J Parasitol. 2009;95:578-80.

254. Jinks MR, English RV, Gilger BC. Causes of endogenous uveitis in cats presented to referral clinics in North Carolina. Vet Ophthalmol. 2016;19:30-7.

255. Tomas A, Pultorak EL, Gruen ME, Breitschwerdt EB, Lascelles BDX. Relationship between degenerative joint disease, pain, and Bartonella spp. seroreactivity in domesticated cats. J Vet Intern Med. 2015;29:21-7.

256. Lappin MR, Hawley J. Presence of Bartonella species and Rickettsia species DNA in the blood, oral cavity, skin and claw beds of cats in the United States. Vet Dermatol. 2009:20:509-14.

257. Luria BJ, Levy JK, Lappin MR, Breitschwerdt EB, Legendre AM, Hernandez JA, et al. Prevalence of infectious diseases in feral cats in northern Florida. J Feline Med Surg. 2004;6:287-96.

258. Fleischman DA, Chomel BB, Kasten RW, Stuckey MJ, Scarlet J, Liu H, et al. Bartonella infection among cats adopted from a San Francisco shelter, revisited. Appl Environ Microbiol. 2015;81:6446-50.

259. Eberhardt JM, Neal K, Shackelford T, Lappin MR. Prevalence of selected infectious disease agents in cats from Arizona. J Feline Med Surg. 2006;8:164-8

260. Cicuttin GL, Brambati DF, De Gennaro MF, Carmona F, Isturiz ML, Pujol LE, et al. Bartonella spp. in cats from Buenos Aires, Argentina. Vet Microbiol. 2014; 168:225-8.

261. Drummond MR, Lania BG, de Paiva Diniz PP, Gilioli R, Demolin DMR, Scorpio DG, et al. Improvement of Bartonella henselae DNA detection in cat blood samples by combining molecular and culture methods. J Clin Microbiol. 2018;56:e01732-17.

262. Vissotto De Paiva Diniz PP, Maggi RG, Schwartz DS, Cadenas MB, Bradley JM, Hegarty B, et al. Canine bartonellosis: serological and molecular prevalence in Brazil and evidence of co-infection with Bartonella henselae and Bartonella vinsonii subsp. berkhoffii. Vet. Res. 2007;38:697-710.

263. Braga MD, Diniz PP, André MR, de Bortoli CP, Machado RZ. Molecular characterisation of Bartonella species in cats from São Luís, state of Maranhão, north-eastern Brazil. Mem Inst Oswaldo Cruz. 2012;107:772-7.

264. Fontalvo MC, Favacho ARM, Araujo AC, Santos NMD, Oliveira GMB, Aguiar DM, et al. Bartonella species pathogenic for humans infect pets, freeranging wild mammals and their ectoparasites in the Caatinga biome, northeastern Brazil: a serological and molecular study. Brazilian J Infect Dis. 2017;21:290-6.

265. Müller A, Walker R, Bittencourt P, Machado RZ, Benevenute JL, DO Amaral $\mathrm{RB}$, et al. Prevalence, hematological findings and genetic diversity of Bartonella spp. in domestic cats from Valdivia, southern Chile. Parasitology. 2017;144:773-82.

266. Ferrés M, Abarca K, Godoy P, García P, Palavecino E, Méndez G, et al. Presence of Bartonella henselae in cats: natural reservoir quantification and human exposition risk of this zoonoses in Chile. Rev Med Chil. 2005;133:1465-71.

267. Levy JK, Crawford PC, Lappin MR, Dubovi EJ, Levy MG, Alleman R, et al. Infectious diseases of dogs and cats on Isabela Island, Galapagos. J Vet Intern Med. 2008;22:60-5.

268. Bai Y, Rizzo MF, Alvarez D, Moran D, Peruski LF, Kosoy M. Coexistence of Bartonella henselae and B. clarridgeiae in populations of cats and their fleas in Guatemala. J Vector Ecol. 2015;40:327-32.

269. Proboste T, Kalema-Zikusoka G, Altet L, Solano-Gallego L, Fernández de Mera IG, Chirife AD, et al. Infection and exposure to vector-borne pathogens in rural dogs and their ticks, Uganda. Parasit Vectors. 2015;8:306.

270. Azzag N, Petit E, Gandoin C, Bouillin C, Ghalmi F, Haddad N, et al. Prevalence of select vector-borne pathogens in stray and client-owned dogs from Algiers. Comp Immunol Microbiol Infect Dis. 2015;38:1-7.

271. Kernif T, Aissi M, Doumandji S-E, Chomel BB, Raoult D, Bitam I. Molecular evidence of Bartonella infection in domestic dogs from Algeria, North Africa, by polymerase chain reaction (PCR). Am J Trop Med Hyg. 2010;83:298-300.

272. Henn JB, Vanhorn BA, Kasten RW, Kachani M, Chomel BB. Antibodies to Bartonella vinsonii subsp. berkhoffii in Moroccan dogs. Am J Trop Med Hyg 2006;74:222-3.

273. Williams BM, Berentsen A, Shock BC, Teixiera M, Dunbar MR, Becker MS, et al. Prevalence and diversity of Babesia, Hepatozoon, Ehrlichia, and Bartonella in wild and domestic carnivores from Zambia, Africa. Parasitol Res. 2014;113:911-8.

274. Kelly PJ, Eoghain GN, Raoult D. Antibodies reactive with Bartonella henselae and Ehrlichia canis in dogs from the communal lands of Zimbabwe. J S Afr Vet Assoc. 2004;75:116-20. 
275. Clarke LL, Ballweber LR, Allen K, Little SE, Lappin MR. Prevalence of select vector-borne disease agents in owned dogs of Ghana. J S Afr Vet Assoc. 2014;85:996.

276. Chomel BB, McMillan-Cole AC, Kasten RW, Stuckey MJ, Sato S, Maruyama S, et al. Candidatus Bartonella merieuxii, a potential new zoonotic Bartonella species in canids from Iraq. PLoS Negl Trop Dis. 2012;6:1843.

277. Baneth G, Breitschwerdt EB, Hegarty BC, Pappalardo B, Ryan J. A survey of tick-borne bacteria and protozoa in naturally exposed dogs from Israel. Vet Parasitol. 1998;74:133-42

278. Celebi B, Carhan A, Kilic S, Babur C. Detection and genetic diversity of Bartonella vinsonii subsp. berkhoffii strains isolated from dogs in Ankara, Turkey. J Vet Med Sci. 2010;72:969-73.

279. Suh G-H, Ahn K-S, Ahn J-H, Kim H-J, Leutenegger C, Shin S. Serological and molecular prevalence of canine vector-borne diseases (CVBDs) in Korea. Parasit Vectors. 2017;10:146.

280. Han Jl, Chang DW, Na KJ. A multiplex quantitative real-time polymerase chain reaction panel for detecting neurologic pathogens in dogs with meningoencephalitis. J Vet Sci. 2015;16:341-7.

281. Brenner EC, Chomel BB, Singhasivanon OU, Namekata DY, Kasten RW, Kass $\mathrm{PH}$, et al. Bartonella infection in urban and rural dogs from the tropics: Brazil, Colombia, Sri Lanka and Vietnam. Epidemiol Infect. 2013;141:54-61.

282. Suksawat J, Xuejie Y, Hancock SI, Hegarty BC, Nilkumhang P, Breitschwerdt EB. Serologic and molecular evidence of coinfection with multiple vectorborne pathogens in dogs from Thailand. J Vet Intern Med. 2001;15:453-62.

283. Billeter SA, Sangmaneedet S, Kosakewich RC, Kosoy MY. Bartonella species in dogs and their ectoparasites from Khon Kaen Province, Thailand. Southeast Asian J Trop Med Public Health. 2012;43:1186-92.

284. Inoue K, Maruyama S, Kabeya H, Kawanami K, Yanai K, Jitchum S, et al. Prevalence of Bartonella infection in cats and dogs in a metropolitan area, Thailand. Epidemiol Infect. 2009;137:1568.

285. Shapiro AJ, Brown G, Norris JM, Bosward KL, Marriot DJ, Balakrishnan N, et al. Vector-borne and zoonotic diseases of dogs in north-west New South Wales and the Northern Territory, Australia. BMC Vet Res. 2017;13:238.

286. Honadel TE, Chomel BB, Yamamoto K, Chang C, Farver TB. Seroepidemiology of Bartonella vinsonii subsp berkhoffii exposure among healthy dogs. J Am Vet Med Assoc. 2001;219:480-4.

287. Diniz PPVP, Beall MJ, Omark K, Chandrashekar R, Daniluk DA, Cyr KE, et al. High prevalence of tick-borne pathogens in dogs from an Indian reservation in northeastern Arizona. Vector Borne Zoonotic Dis. 2010;10:117-23.

288. Henn JB, Gabriel MW, Kasten RW, Brown RN, Theis JH, Foley JE, et al. Gray foxes (Urocyon cinereoargenteus) as a potential reservoir of a Bartonella clarridgeiae-like bacterium and domestic dogs as part of a sentinel system for surveillance of zoonotic arthropod-borne pathogens in northern California. J Clin Microbiol. 2007:45:2411-8

289. de Paiva Diniz PPV, Schwartz DS, de Morais HSA, Breitschwerdt EB. Surveillance for zoonotic vector-borne infections using sick dogs from southeastern Brazil. Vector Borne Zoonotic Dis. 2007;7:689-97.

290. Müller A, Soto F, Sepúlveda M, Bittencourt P, Benevenute JL, Ikeda P, et al. Bartonella vinsonii subsp. berkhoffii and B. henselae in dogs. Epidemiol Infect. 2018;146:1202-4.

291. Diniz PPVP, Morton BA, Tngrian M, Kachani M, Barrón EA, Gavidia CM, et al Infection of domestic dogs in Peru by zoonotic Bartonella species: a crosssectional prevalence study of 219 asymptomatic dogs. PLoS Negl Trop Dis. 2013;7:e2393.

292. Guptill L, Slater L, Wu CC, Lin TL, Glickman LT, Welch DF, et al. Experimental infection of young specific pathogen-free cats with Bartonella henselae. J Infect Dis. 1997:176:206-16.

293. Chomel BB, Wey AC, Kasten RW, Stacy BA, Labelle P. Fatal case of endocarditis associated with Bartonella henselae type I infection in a domestic cat. J Clin Microbiol. 2003;41:5337-9.

294. Perez C, Hummel JB, Keene BW, Maggi RG, Diniz PPVP, Breitschwerdt EB. Successful treatment of Bartonella henselae endocarditis in a cat. J Feline Med Surg. 2010;12:483-6.

295. Ketring KL, Zuckerman EE, Hardy WDJ. Bartonella: a new etiological agent of feline ocular disease. J Am Anim. 2004;40:6.

296. Whittemore JC, Hawley JR, Radecki SV, Steinberg JD, Lappin MR. Bartonella species antibodies and hyperglobulinemia in privately owned cats. J Vet Intern Med. 2012;26:639-44.

297. Breitschwerdt EB, Hegarty BC, Hawkins E, Dyer P, Maggi R. Bartonella species as a potential cause of epistaxis in dogs. J Clin Microbiol. 2005:43:2529-33.
298. Goodman RA, Breitschwerdt EB. Clinicopathologic findings in dogs seroreactive to Bartonella henselae antigens. Am J Vet Res. 2005;66:2060-4.

299. Vuković-Arar Z, Janjetović Z, Sekelj S, Sapina L, Pajić-Penavić I. Neuroretinitis caused by Bartonella quintana. Med Glas. 2012;9:435-7.

300. Kalogeropoulos C, Koumpoulis I, Mentis A, Pappa C, Zafeiropoulos P, Aspiotis M. Bartonella and intraocular inflammation: a series of cases and review of literature. Clin Ophthalmol. 2011;5:817-29.

301. Caniza MA, Granger DL, Wilson KH, Washington MK, Kordick DL, Frush DP et al. Bartonella henselae: etiology of pulmonary nodules in a patient with depressed cell-mediated immunity. Clin Infect Dis. 1995;20:1505-11.

302. Chomel BB, Ermel RW, Kasten RW, Henn JB, Fleischman DA, Chang CC. Experimental infection of dogs with various Bartonella species or subspecies isolated from their natural reservoir. Vet Microbiol. 2014;168:169-76.

303. Chomel BB, Henn JB, Kasten RW, Nieto NC, Foley J, Papageorgiou S, et al. Dogs are more permissive than cats or guinea pigs to experimental infection with a human isolate of Bartonella rochalimae. Vet Res. 2009;40:27.

304. Chomel BB, Kasten RW, Stuckey MJ, Breitschwerdt EB, Maggi RG, Henn JB, et al. Experimental infection of cats with Afipia felis and various Bartonella species or subspecies. Vet Microbiol. 2014;172:505-10.

305. Donovan T, Balakrishnan N, Carvalho Barbosa I, McCoy T, Breitschwerdt E, Fox P. Bartonella spp. as a possible cause or cofactor of feline endomyocarditis-left ventricular endocardial fibrosis complex. J Comp Pathol. 2018;162:29-42.

\section{Ready to submit your research? Choose BMC and benefit from:}

- fast, convenient online submission

- thorough peer review by experienced researchers in your field

- rapid publication on acceptance

- support for research data, including large and complex data types

- gold Open Access which fosters wider collaboration and increased citations

- maximum visibility for your research: over $100 \mathrm{M}$ website views per year

At BMC, research is always in progress.

Learn more biomedcentral.com/submissions 